\title{
Nitrogen nutrition in assemblages dominated by Pseudo-nitzschia spp., Alexandrium catenella and Dinophysis acuminata off the west coast of South Africa
}

\author{
S. Seeyave ${ }^{1, *}$, T. A. Probyn ${ }^{2}$, G. C. Pitcher ${ }^{2}$, M. I. Lucas ${ }^{3}$, D. A. Purdie ${ }^{1}$ \\ ${ }^{1}$ National Oceanography Centre, University of Southampton, European Way, Southampton SO14 3ZH, UK \\ ${ }^{2}$ Marine \& Coastal Management, Private Bag X2, Rogge Bay 8012, Cape Town, South Africa \\ ${ }^{3}$ Zoology Department, University of Cape Town, Rondebosch 7701, South Africa
}

\begin{abstract}
A study was carried out in the southern Benguela upwelling system in 2006 and 2007 to establish how the nutrient regime determines community succession and the selection of harmful algal bloom species. In March 2006, Pseudo-nitzschia spp. reached concentrations of $13 \times 10^{6} \mathrm{cells}^{-1}$, representing $80 \%$ of the total estimated phytoplankton biomass, while chlorophyll a $(\mathrm{chl}$ a) reached

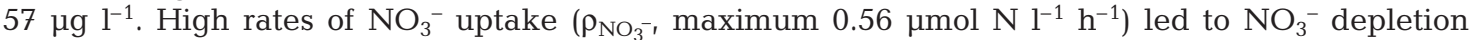
$(<0.1 \mu \mathrm{M})$. However, cell numbers remained high for several days, sustained by regenerated nitrogen, with $f$-ratios dropping from 0.79 to 0.12. In March 2007, a bloom of Alexandrium catenella (4.5× $10^{5}$ cells $^{-1}, 77 \%$ of the phytoplankton biomass) occurred, with surface chl a concentrations of $26 \mu \mathrm{g}$

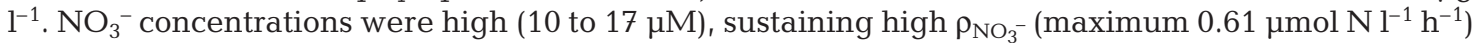
and $f$-ratios up to 0.87 . In April, Dinophysis acuminata reached $3.1 \times 10^{4}$ cells $\mathrm{l}^{-1}$ (91\% phytoplankton biomass), with $\mathrm{NO}_{3}{ }^{-}$concentrations $<0.5 \mu \mathrm{M}$ and $f$-ratios $<0.1$, indicative of regenerated production. Nutrient uptake kinetics showed that Pseudo-nitzschia spp. displayed the highest maximum specific uptake rates $\left(15.0 \times 10^{-3}\right.$ and $18.0 \times 10^{-3} \mathrm{~h}^{-1}$ for $\mathrm{NO}_{3}{ }^{-}$and $\mathrm{NH}_{4}{ }^{+}$, respectively). D. acuminata displayed the highest affinity for $\mathrm{NH}_{4}{ }^{+}$, as shown by its higher $\alpha$ (slope of the nutrient uptake vs. concentration curve) of $20.7 \times 10^{-3}$, compared to $13.4 \times 10^{-3}$ and $5.9 \times 10^{-3} \mathrm{~h}^{-1}\left(\mu \mathrm{mol} \mathrm{N}{ }^{-1}\right)^{-1}$ for Pseudonitzschia spp. and A. catenella, respectively. D. acuminata was an affinity strategist, successful in nitrogen-depleted waters, whereas both Pseudo-nitzschia spp. and A. catenella were velocity strategists, better adapted to utilising high $\mathrm{NO}_{3}{ }^{-}$concentrations during upwelling pulses.
\end{abstract}

KEY WORDS: Benguela upwelling system - Harmful algal blooms · Nutrient uptake . Nutrient kinetics · Dinoflagellates · Diatoms

\section{INTRODUCTION}

Harmful algal blooms (HABs) are a regular occurrence on the west coast of South Africa, within the southern Benguela upwelling system, in late austral summer (February to April). HAB species in the Benguela include both high biomass producers, whose blooms can cause oxygen depletion and hydrogen sulfide production, and toxin producers, which are potential vectors of paralytic, diarrhetic and amnesic shellfish poisoning (PSP, DSP, ASP) (Pitcher \& Calder 2000). PSP is typically attributed to Alexandrium catenella (Pitcher \& Calder 2000), al- though a bloom of A. minutum in Cape Town harbour has recently been reported (Pitcher et al. 2007), indicating the potential threat posed by this species. In South Africa, DSP was first reported in 1991 on the west coast and attributed to Dinophysis acuminata (Pitcher et al. 1993b). Dinophysis spp. cell concentrations up to $4 \times$ $10^{4}$ cells l$^{-1}$ were recorded in March/ April 2005 off Lambert's Bay in association with okadaic acid (OA) concentrations of up to $0.4 \mu \mathrm{g} \mathrm{l}^{-1}$ (Fawcett et al. 2007). Pseudo-nitzschia spp. (hereafter Pseudo-nitzschia) blooms also occur in the southern Benguela and were linked with high concentrations of domoic acid (up to 
$3 \mathrm{\mu g}^{-1}$ ) for the first time in March 2006 off Lambert's Bay (Fawcett et al. 2007), although no cases of ASP have yet been reported.

The HAB taxa that occur in the southern Benguela also form blooms in the other eastern boundary upwelling systems. For example, Dinophysis acuminata and $D$. acuta blooms occur in the Iberian upwelling system (Reguera et al. 1993), blooms of Pseudonitzschia pseudodelicatissima, P. australis and P. multiseries occur in the California upwelling system (Buck et al. 1992, Adams et al. 2000, Trainer et al. 2001) and Alexandrium catenella blooms occur in the Humboldt (Avaria 1979) and California systems (Nishitani \& Chew 1988). HABs around the South African coast are closely associated with the upwelling system, as they are generally restricted to the west of Cape Agulhas (Fig. 1) (Pitcher \& Calder 2000). They are particularly frequent north of Cape Columbine, where the broad southern Namaqua shelf favours stratification (Fig. 1). Blooms tend to occur towards the end of the upwelling season (March to April), when reduced wind stress and increased thermal stratification favour dinoflagellates

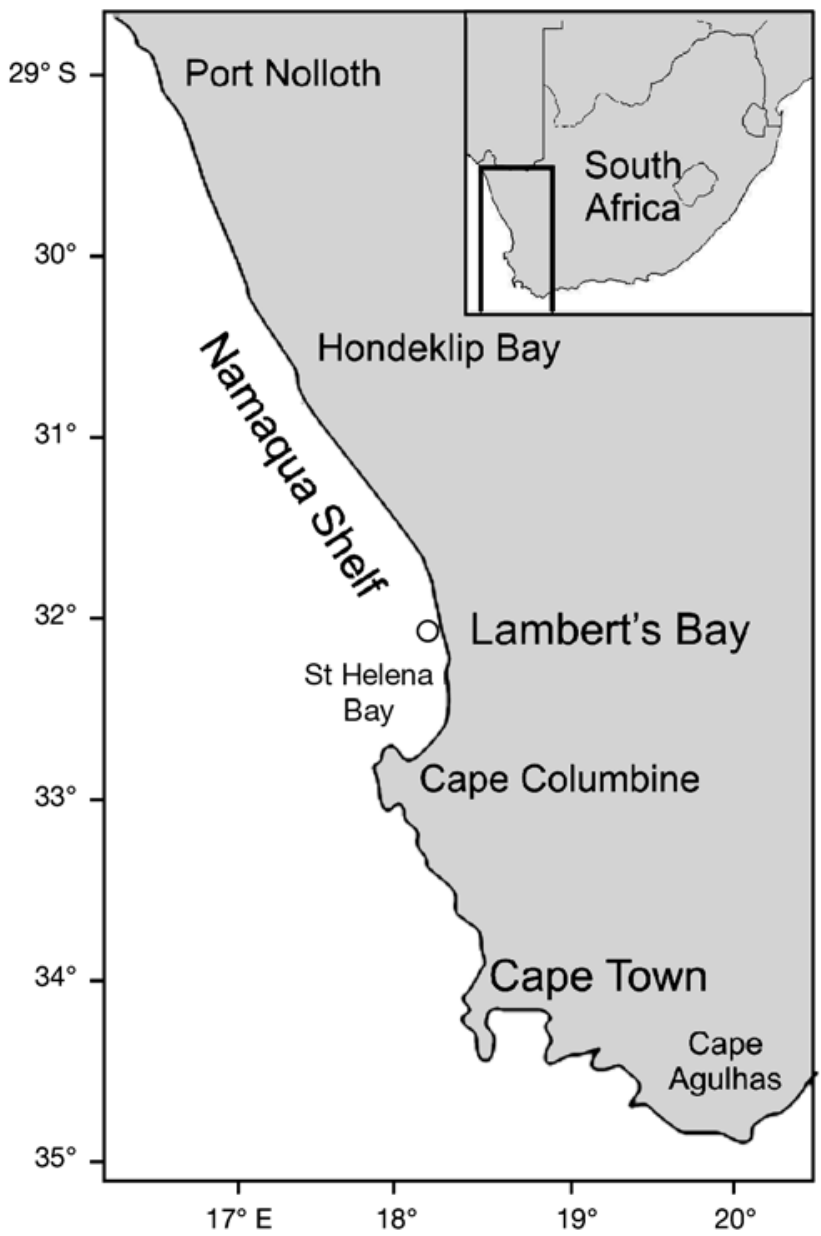

Fig. 1. West Coast of South Africa, showing the sampling station $3.5 \mathrm{~km}$ off Lambert's Bay (O)
(Pitcher et al. 1993a). Within these periods, community succession is dictated by local wind patterns, whereby upwelling-favourable winds and a well-mixed water column tend to favour diatoms, whereas upwelling relaxation is conducive to dinoflagellate blooms (Fawcett et al. 2007) and can lead to their onshore advection (Pitcher \& Boyd 1996, Pitcher et al. 1998). The persistence of stratified conditions, however, leads to a decline in biomass and a shift in community composition towards small flagellates, in particular coccolithophorids (Pitcher \& Boyd 1996, Pitcher et al. 1998, Fawcett et al. 2007). The link between HABs, upwelling relaxation and onshore advection has also been reported for the Iberian (Tilstone et al. 1994) and Californian (Trainer et al. 2002) upwelling systems.

According to Margalef's Mandala (Margalef 1978), the seasonal shift from diatoms in spring to dinoflagellates in summer occurs along a gradient of decreasing turbulence and nutrient availability. However, the 'red tide sequence' occurs under the anomalous combination of low turbulence/high nutrient conditions (Margalef et al. 1979), which fits with the apparent low affinity of dinoflagellates for nitrogen uptake relative to diatoms (Smayda 1997, Collos et al. 2005). However, HABs in upwelling systems tend to occur at the end of the upwelling season under stratified and nutrientdepleted conditions (Tilstone et al. 1994, Pitcher \& Boyd 1996); therefore, they must have evolved adaptive strategies allowing survival under such conditions. In addition to the 4 adaptations suggested by Smayda (1997) (nutrient retrieval migrations, mixotrophy, secretion of allelochemicals and allelopathy), utilisation of recycled nitrogen sources may be significant in situations where 'new' nitrogen is depleted.

It has been hypothesised that diatoms may express a preference for nitrate $\left(\mathrm{NO}_{3}{ }^{-}\right)$over ammonium $\left(\mathrm{NH}_{4}{ }^{+}\right)$ (Malone 1980), and several studies have shown that flagellates (Glibert et al. 1982a, Probyn 1985) and dinoflagellates can be sustained by regenerated nitrogen, e.g. Alexandrium catenella in the Thau Lagoon, France (Collos et al. 2007) and HAB assemblages including Dinophysis acuta and Gymnodinium catenatum in the Iberian upwelling system (Rios et al. 1995). However, laboratory studies have shown preferences for either $\mathrm{NO}_{3}{ }^{-}$or $\mathrm{NH}_{4}{ }^{+}$(as shown by parameters of nutrient uptake kinetics for $\mathrm{NO}_{3}^{-}$and $\mathrm{NH}_{4}{ }^{+}$) in both diatom and dinoflagellate species (Dortch 1990). Furthermore, the nitrogen status of the cell can influence its preference for either form of nitrogen (Collos \& Slawyk 1979) or its ability to compete for a specific nutrient (Riegman et al. 1996). Pseudo-nitzschia blooms on the United States West coast have been attributed to either elevated $\mathrm{NO}_{3}{ }^{-}$(Horner et al. 2000, Marchetti et al. 2004) or $\mathrm{NH}_{4}{ }^{+}$concentrations (Trainer et al. 2007). Field populations of $P$. australis from Cali- 
fornia were found to grow equally well on $\mathrm{NO}_{3}{ }^{-}, \mathrm{NH}_{4}{ }^{+}$, or urea (Howard et al. 2007); however, P. australis cultures exhibited lower growth rates supported by urea relative to $\mathrm{NO}_{3}{ }^{-}$and $\mathrm{NH}_{4}{ }^{+}$and a preference for $\mathrm{NO}_{3}{ }^{-}$ (higher maximum uptake rates $v_{\max }$ and lower halfsaturation constants $K_{\mathrm{s}}$ ) relative to recycled nitrogen forms (Cochlan et al. 2008).

We hypothesise that the success of HAB species in the southern Benguela at the end of the upwelling season could be attributable to their ability to utilise alternative nitrogen sources or to their high affinity for $\mathrm{NO}_{3}{ }^{-}$under low $\mathrm{NO}_{3}{ }^{-}$conditions.

To test this hypothesis, regular measurements of nitrogen uptake rates $\left(\mathrm{NO}_{3}{ }^{-}, \mathrm{NH}_{4}{ }^{+}\right.$and urea) were performed in conjunction with hydrographic and other biological measurements during $\sim 3$ wk sampling periods in 2006 and 2007 off Lambert's Bay on the West coast of South Africa. In addition, experiments in nutrient uptake kinetics were performed during blooms of Pseudo-nitzschia, Alexandrium catenella and Dinophysis acuminata.

\section{MATERIALS AND METHODS}

Sampling. Sampling was carried out between 7 and 23 March 2006 and between 20 March and 11 April 2007 at the same station, $3.5 \mathrm{~km}$ off Lambert's Bay $\left(32^{\circ} 05.020^{\prime} \mathrm{S}, 18^{\circ} 16.010^{\prime} \mathrm{E}\right.$; Fig. 1) in $\sim 50 \mathrm{~m}$ water.

Vertical profiles of temperature and fluorescence were established using a Seabird Electronics Seacat CTD coupled with a Wetstar fluorometer. Discrete water samples were taken daily from 5 depths $(0,5,10,15,20 \mathrm{~m})$ for chlorophyll a (chl a) analyses. Samples for ${ }^{15} \mathrm{~N}$ incubations were taken at 2 depths: at the surface $(0 \mathrm{~m})$ and a subsurface depth that was $5 \mathrm{~m}$ on all dates in 2007 and on most dates in 2006, execept for 10 and 11 March 2006 where it was $10 \mathrm{~m}$. Samples for phosphate $\left(\mathrm{PO}_{4}{ }^{3-}\right)$, silicic acid $\left[\mathrm{Si}(\mathrm{OH})_{4}\right.$, hereafter $\left.\mathrm{Si}\right]$, nitrite $\left(\mathrm{NO}_{2}{ }^{-}\right), \mathrm{NO}_{3}{ }^{-}, \mathrm{NH}_{4}{ }^{+}$ and urea concentrations were only taken at 2 depths in 2006, but at all 5 depths in 2007. Phytoplankton counts were performed on surface samples only. All water was collected using 51 Niskin bottles and transported ashore in dark containers within $1 \mathrm{~h}$ of collection. Incubations and nutrient and chl $a$ analyses were performed ashore in Lambert's Bay, whereas the more timeconsuming analyses (e.g. $\mathrm{NH}_{4}{ }^{+}$recovery and mass spectrometry) were carried out at a later date either in Cape Town or Southampton (UK). Wind data were obtained from a weather station exposed to maritime wind conditions, situated at $97 \mathrm{~m}$ altitude and $8.5 \mathrm{~km}$ from the sampling station (South African Weather Service).

Statistical data analysis. Where comparisons were made between groups of data (e.g. 2006 vs. 2007), Student's $t$-tests were applied, provided that variances within each group were not significantly different (as determined by a 2-tailed $F$-test). Paired $t$-tests were used for comparing simultaneous surface and subsurface measurements or measurements of different parameters made on the same water sample. The nonparametric Mann-Whitney $U$-test was employed when variances were significantly different. The level of confidence used to determine significance was 95\% ( $p<$ $0.05)$; therefore, the $\mathrm{p}$-value is only shown when higher levels of confidence were achieved.

Nutrients. All nutrients were determined manually within $2 \mathrm{~h}$ of collection after filtration through $25 \mathrm{~mm}$ Whatman GF/F filters. $\mathrm{NO}_{3}^{-}$concentrations were determined colourimetrically after reduction to $\mathrm{NO}_{2}{ }^{-}$ on a cadmium column and corrected for ambient $\mathrm{NO}_{2}^{-}$ (Nydahl 1976). Concentrations of $\mathrm{Si}, \mathrm{PO}_{4}{ }^{3-}, \mathrm{NH}_{4}{ }^{+}, \mathrm{NO}_{2}{ }^{-}$ and urea were measured following Grasshoff et al. (1999) and scaled to $5 \mathrm{ml}$ sample volumes.

Chl $a$ and phytoplankton concentrations. Water samples $(100 \mathrm{ml})$ collected for the determination of chl a concentrations were filtered onto $25 \mathrm{~mm}$ Whatman GF/F filters, ground and extracted in $9 \mathrm{ml}$ of $90 \%$ acetone for at least $24 \mathrm{~h}$ at $-20^{\circ} \mathrm{C}$ in the dark, then centrifuged for $10 \mathrm{~min}$. Duplicate measurements were carried out in association with nutrient uptake incubations. Fluorescence was determined using a Turner Designs 10-AU fluorometer calibrated with commercial chl a (Sigma). Fluorescence readings were taken before and after acidification with 2 drops $10 \% \mathrm{HCl}$ to correct for phaeopigments (Parsons et al. 1984).

Phytoplankton samples $(100 \mathrm{ml})$ were preserved in $2.5 \%$ buffered formalin and counted using inverted microscopy (Utermöhl 1958). Identification was to species level where possible. Three species of Pseudonitzschia were enumerated, including $P$. australis and 2 unidentified species. The most abundant of these 2 ('Species 1') had an apical axis of $38 \mu \mathrm{m}( \pm 6 \mu \mathrm{m}, \mathrm{n}=20)$ and a transapical axis of $3.4 \mu \mathrm{m}( \pm 0.6 \mu \mathrm{m}, \mathrm{n}=20)$. 'Species 2 ' only represented 0 to $16 \%$ of the total Pseudonitzschia concentrations and was a small species with a transapical axis of $<3 \mu \mathrm{m}$. For the experiments in nutrient uptake kinetics, biomass estimates were made to determine the dominance of Pseudo-nitzschia, Alexandrium catenella and Dinophysis acuminata in the 3 experiments, respectively. Cell volumes were calculated from cell measurements and stereometric shapes (Hillebrand et al. 1999). Biovolume-to-carbon conversions were then applied following the equations of Menden-Deuer \& Lessard (2000):

$$
\begin{gathered}
\text { Dinoflagellates: } C_{\text {cell }}=0.760 \times V^{0.819} \\
\text { Diatoms: } C_{\text {cell }}=0.288 \times V^{0.811}
\end{gathered}
$$

where $C_{\text {cell }}$ is cellular carbon content (pg C cell ${ }^{-1}$ ) and $V$ is cell volume $\left(\mu^{3}\right)$. 
Due to the low number of species in these experiments and their consistent cell sizes, these estimates were considered to be robust.

Multivariate analyses were performed on the count data using PRIMER (V. 5). Between-station similarities were calculated using the Bray-Curtis similarity index based on standardised cell concentrations after square root transformation. The similarity matrices obtained were then used to perform cluster analyses and multidimensional scaling (MDS). The last station in 2007 was distinct from all others at the $60 \%$ similarity level in the cluster analysis. Since the objective was to identify similarities within clusters of stations, it was excluded from the MDS analysis. Similarity percentage (SIMPER) analysis was performed on standardised count data after square root transformation, to determine species' contribution to similarity within the clusters identified at the $60 \%$ similarity level. The Shannon diversity index (Shannon 1948) was calculated (using PRIMER) from:

$$
H^{\prime}=-\sum_{\mathrm{i}=1}^{S} p_{i} \ln p_{i}
$$

where $S$ is the number of species and $p_{i}$ is the proportion of each species $i$ relative to total phytoplankton abundance.

Nutrient uptake. Standard nutrient uptake incubations: Two 11 and one 21 water samples taken from the surface and subsurface were dispensed into Nalgene polycarbonate bottles. The 11 samples were inoculated with stock solutions of $1 \mathrm{mmol}{ }^{15} \mathrm{~N}^{-1}$ (Prochem, BOC), as either $\mathrm{K}^{15} \mathrm{NO}_{3}$ (99.6 at.\%) or $\mathrm{CO}\left({ }^{15} \mathrm{NH}_{2}\right)_{2}$ (99.1 at.\%), whereas the $2 \mathrm{l}$ sample was inoculated with ${ }^{15} \mathrm{NH}_{4} \mathrm{Cl}$ (99.7 at.\%). Aqueous enrichments after spike addition were, on average, $23.1 \%( \pm 19.7 \%)$ in 2006 and $21.4 \%$ $( \pm 16.3 \%)$ in 2007 . Samples were incubated in Perspex incubation tubes for $3 \mathrm{~h}$ (generally starting between 11:15 and 12:00 h) at simulated in situ temperatures (11 to $17^{\circ} \mathrm{C}$ ) and irradiances $(50 \%$ shading was achieved with neutral density filters [Lee] for the subsurface samples). Incubations were terminated by filtration onto $47 \mathrm{~mm}$ precombusted GF/F filters (Whatman), which were then rinsed with artificial seawater and dried $\left(75^{\circ} \mathrm{C}\right.$, overnight). Between 5 and 10 small $(5 \mathrm{~mm}$ diameter) discs were punched out of each filter, depending on the amount of material present, and pelletted into tin capsules (Pellican Scientific $5 \times 9 \mathrm{~mm}$ ). Isotopic composition and particulate nitrogen (PN) concentrations were determined on a GV Instruments IsoPrime stable isotope mass spectrometer interfaced with a EuroVector Euro EA elemental analyser.

Uptake rates were calculated from Eqs. (1) to (3) of Dugdale \& Wilkerson (1986), corrected for isotopic dilution of ${ }^{15} \mathrm{NH}_{4}{ }^{+}$by regenerated ${ }^{14} \mathrm{NH}_{4}{ }^{+}$according to Glibert et al. (1982b).

Filtrates from the start and end of each incubation were returned frozen to the Marine \& Coastal Management laboratory in Cape Town, where aqueous $\mathrm{NH}_{4}{ }^{+}$was recovered by diffusion onto ashed and halved $25 \mathrm{~mm}$ GF/F filters (Probyn 1987) with $\mathrm{KHSO}_{4}$ as the trapping agent. Filters were processed and analysed in the same way as the ${ }^{15} \mathrm{~N}$ uptake samples to determine aqueous enrichment at the start $\left(R_{0}\right)$ and end $\left(R_{t}\right)$ of the incubations.

Nutrient uptake kinetics: On 16 March 2006, an experiment was undertaken on a sample from $5 \mathrm{~m}$ water depth dominated by Pseudo-nitzschia (80\% total estimated phytoplankton carbon biomass, $\sim 57 \%$ of

Table 1. Phytoplankton species' contribution to total between-station similarity derived from SIMPER analysis performed on clusters defined at the $60 \%$ similarity level and mean $( \pm \mathrm{SD})$ Shannon diversity indices $\left(H^{\prime}\right)$, surface temperatures, $\mathrm{NO}_{3}{ }^{-}$concentrations and $f$-ratios for each cluster (assemblage type)

\begin{tabular}{|c|c|c|c|c|c|c|c|}
\hline $\begin{array}{l}\text { Assemblage } \\
\text { type }\end{array}$ & Dates & Species & $\begin{array}{l}\text { Percent } \\
\text { contribution to } \\
\text { total similarity }\end{array}$ & $H^{\prime}$ & $\begin{array}{l}\text { Temp. } \\
\left({ }^{\circ} \mathrm{C}\right)\end{array}$ & $\begin{array}{l}\mathrm{NO}_{3}^{-} \\
(\mu \mathrm{M})\end{array}$ & $f$-ratio \\
\hline I & 20, 21, 28 Mar 2007 & $\begin{array}{l}\text { Skeletonema costatum } \\
\text { Alexandrium catenella } \\
\text { Thalassiosira spp. } \\
\text { Scrippsiella trochoidea }\end{array}$ & $\begin{array}{l}31.6 \\
21.3 \\
16.2 \\
11.5\end{array}$ & $1.5 \pm 0.4$ & $11.5 \pm 0.3$ & $16.5 \pm 6.3$ & $0.56 \pm 0.46$ \\
\hline II & 4, 5, 8-10 Apr 2007 & $\begin{array}{l}\text { Gymnodinium spp. } \\
\text { Dinophysis acuminata }\end{array}$ & $\begin{array}{r}93.1 \\
6.2\end{array}$ & $0.3 \pm 0.3$ & $16.3 \pm 0.4$ & $0.2 \pm 0.2$ & $0.07 \pm 0.02$ \\
\hline III & $\begin{array}{l}\text { 22-27, 29-31 Mar, } \\
\text { 2-3 Apr } 2007\end{array}$ & $\begin{array}{l}\text { S. costatum } \\
\text { Chaetoceros spp. } \\
\text { Pseudo-nitzschia spp. } \\
\text { Bacteriastrum spp. }\end{array}$ & $\begin{array}{l}29.2 \\
28.6 \\
18.5 \\
11.0\end{array}$ & $1.1 \pm 0.3$ & $13.6 \pm 1.4$ & $4.9 \pm 8.4$ & $0.25 \pm 0.16$ \\
\hline IV & 1, 6, 7 Apr 2007 & $\begin{array}{l}\text { Chaetoceros spp. } \\
\text { Pseudo-nitzschia spp. }\end{array}$ & $\begin{array}{l}72.0 \\
11.3\end{array}$ & $0.4 \pm 0.1$ & $16.2 \pm 0.9$ & $0.3 \pm 0.4$ & $0.15 \pm 0.12$ \\
\hline $\mathrm{V}$ & 7-23 Mar 2006 & $\begin{array}{l}\text { Pseudo-nitzschia spp. } \\
\text { Chaetoceros spp. }\end{array}$ & $\begin{array}{l}61.5 \\
34.8\end{array}$ & $0.7 \pm 0.2$ & $12.7 \pm 1.3$ & $9.8 \pm 9.6$ & $0.53 \pm 0.26$ \\
\hline
\end{tabular}


which was $P$. australis). In 2007, experiments were undertaken on surface samples dominated by Alexandrium catenella (77\%) on 21 March and by Dinophysis acuminata (91\%) on 8 April.

Subsamples were dispensed from a 51 sample into eighteen $250 \mathrm{ml}$ bottles (rinsed with sample water) and spiked with different volumes of $10 \%$ enriched $\mathrm{KNO}_{3}$, $\mathrm{NH}_{4} \mathrm{Cl}$ and urea solutions ( $1 \mathrm{mmol} \mathrm{N} \mathrm{l}{ }^{-1}$ ). Ambient concentrations are shown in Table 2 and nutrient additions were as follows (mean $\pm \mathrm{SE}, \mathrm{n}=3$ ): $0.19(0.11), 0.48$ (0.27), 1.99 (1.55), 4.85 (2.66), 8.73 (3.25) and 20.16

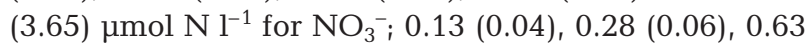
(0.20), 2.13 (0.04), $5.32(0.11)$ and $19.58(2.14) \mu \mathrm{mol} \mathrm{N}$ $\mathrm{l}^{-1}$ for $\mathrm{NH}_{4}^{+}$; and $0.13(0.04), 0.28(0.06), 0.63$ (0.19),

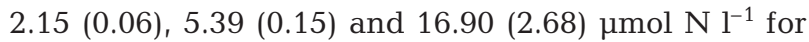
urea. The aqueous enrichment was $<10 \%$ at the lowest concentrations, which was sometimes problematic when the ambient nutrient concentration was high (see 'Results'). Replication and a greater number of treatments (particularly in the range of subsaturating concentrations) would have been preferable; however, this was not possible due to logistical constraints. Notwithstanding these shortcomings, the $r^{2}$ values obtained for the regressions $(0.88$ to 1.00$)$ and the $p$ values for the parameters (Table 3 ) provide confidence in these estimates.

Samples were incubated for $3 \mathrm{~h}$ under surface temperature and light conditions, then filtered onto $25 \mathrm{~mm}$ precombusted GF/F filters. The proportion of added ${ }^{15} \mathrm{~N}$ incorporated into the particulate phase during the incubations ranged from 18 to $52 \%$ (Expt 1), 37 to $55 \%$ (Expt 2) and 6 to $23 \%$ (Expt 3) at the lowest nitrogen addition; therefore, substrate depletion was not an issue. Samples were analysed in the same way as the standard uptake samples, except that no correction was made for isotope dilution in the $\mathrm{NH}_{4}{ }^{+}$experiments. According to Dugdale \& Wilkerson (1986), this should only be problematic (i.e. lead to an overestimation of $K_{\mathrm{s}}$ ) for incubation lengths $>6 \mathrm{~h}$.

Plots of nutrient uptake versus concentration were fitted to the Michaelis-Menten equation (Dugdale 1967) by iterative, non-linear least-squares regression (SigmaPlot, Jandel Scientific) such that:

$$
v=v_{\max } S /\left(K_{\mathrm{s}}+S\right)
$$

where $v$ is the particulate nitrogen $(\mathrm{PN})$ specific uptake rate $\left(\mathrm{h}^{-1}\right), v_{\max }$ is the maximum PN-specific uptake rate $\left(\mathrm{h}^{-1}\right), S$ is

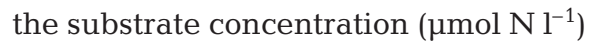
and $K_{\mathrm{s}}$ is the half-saturation constant ( $\mu \mathrm{mol} \mathrm{N}{ }^{-1}$ ). The initial slope of the curve $\alpha$, used as an indicator of nutrient affinity at concentrations $<K_{\mathrm{s}}$, was calculated from $\alpha=v_{\max } / K_{\mathrm{s}}$ (Healey 1980).

Table 3. Parameters of nutrient uptake kinetics $v_{\max }$ and $K_{\mathrm{s}}$ means (SE), derived from Fig. 8 . The initial slope of the curve, $\alpha$, is the ratio $v_{\max } / K_{\mathrm{s}}$. Maximum uptake and $\alpha$ are particulate nitrogen (PN)-specific or cell-specific. ${ }^{*} \mathrm{p}<0.05$; n.d.: not determined

\begin{tabular}{|c|c|c|c|c|c|c|c|c|c|c|}
\hline \multicolumn{5}{|c|}{ PN specific } & \multirow{2}{*}{\multicolumn{3}{|c|}{$K_{\mathrm{s}}\left(\mu \mathrm{mol} \mathrm{N} \mathrm{l^{-1 } )}\right.$}} & \multirow{3}{*}{\multicolumn{3}{|c|}{ 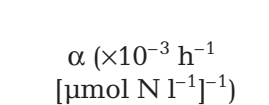 }} \\
\hline Expt & Dominant species & \multirow{3}{*}{$\mathrm{NO}_{3}^{-}$} & \multirow{3}{*}{$\begin{array}{c}\left(\times 10^{-3} \mathrm{l}\right. \\
\mathrm{NH}_{4}^{+}\end{array}$} & \multirow{3}{*}{ Urea } & & & & & & \\
\hline & & & & & \multirow{2}{*}{$\mathrm{NO}_{3}^{-}$} & \multirow[t]{2}{*}{$\mathrm{NH}_{4}^{+}$} & \multirow[t]{2}{*}{ Urea } & & & \\
\hline & & & & & & & & $\mathrm{NO}_{3}^{-}$ & $\mathrm{NH}_{4}^{+}$ & Urea \\
\hline 1 & Pseudo-nitzschia & $15.0(0.4)^{*}$ & * $18.0(0.3)^{*}$ & $4.9(0.3)^{\mathrm{a}}$ & $1.21(0.15)^{*}$ & $1.34(0.07)^{*}$ & n.d. & 12.4 & 13.4 & n.d. \\
\hline 2 & Alexandrium catenella & n.d. & $14.9(0.8)^{*}$ & $3.5(0.2)^{*}$ & n.d. & $2.52(0.36)^{*}$ & $0.65(0.12)^{*}$ & n.d. & 5.9 & 5.4 \\
\hline 3 & Dinophysis acuminata & $3.5(0.2)^{*}$ & $13.9(0.2)^{*}$ & $6.2(0.6)^{*}$ & $0.79(0.26)$ & $0.67(0.06)^{*}$ & $0.53(0.22)$ & 4.4 & 20.7 & 11.7 \\
\hline \multicolumn{5}{|c|}{ Cell specific } & \multirow{2}{*}{\multicolumn{3}{|c|}{$K_{\mathrm{s}}\left(\mu \mathrm{mol} \mathrm{N} \mathrm{l^{-1 }}\right)$}} & \multirow{3}{*}{\multicolumn{3}{|c|}{ 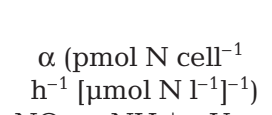 }} \\
\hline \multirow[t]{3}{*}{ Expt } & \multirow[t]{3}{*}{ Dominant species } & \multicolumn{3}{|c|}{$-v_{\max }\left(\right.$ pmol N cell $\left.{ }^{-1} \mathrm{~h}^{-1}\right)-$} & & & & & & \\
\hline & & $\mathrm{NO}_{3}^{-}$ & $\mathrm{NH}_{4}^{+}$ & Urea & \multirow{2}{*}{$\mathrm{NO}_{3}^{-}$} & $\mathrm{NH}_{4}^{+}$ & \multirow[t]{2}{*}{ Urea } & & & \\
\hline & & & & & & & & $\mathrm{NO}_{3}^{-}$ & $\mathrm{NH}_{4}^{+}$ & Urea \\
\hline 1 & Pseudo-nitzschia & 0.02 & 0.03 & 0.01 & 1.21 & 1.34 & n.d. & 0.02 & 0.02 & n.d. \\
\hline 2 & A. catenella & n.d. & 1.30 & 0.31 & n.d. & 2.52 & 0.65 & n.d. & 0.52 & 0.48 \\
\hline 3 & D. acuminata & 0.74 & 2.90 & 1.30 & 0.79 & 0.67 & 0.53 & 0.94 & 4.33 & 2.45 \\
\hline
\end{tabular}


In Expt 1, calculations of $v_{\text {urea }}$ at the 2 lower urea concentrations were not reliable due to a high ambient concentration $\left(1.7 \mu \mathrm{mol} \mathrm{N} \mathrm{^{-1 }}\right)$, which resulted in very low enrichments ( 1 to $2 \%$ ) in these treatments; therefore, it was not possible to estimate $K_{\mathrm{s}}$ in this case. However, since no increase in $v$ was observed at 4 concentrations between 2.7 and $17.0 \mu \mathrm{mol} \mathrm{N}{ }^{-1}, v_{\max }$ of urea could be estimated from the mean of these 4 measurements. The ambient $\mathrm{NO}_{3}{ }^{-}$concentration in Expt 2 was very high $(16.9 \mu \mathrm{M})$; therefore, no estimate could be made for either $K_{\mathrm{s}}$ or $\mathrm{v}_{\text {max }}$ of $\mathrm{NO}_{3}{ }^{-}$.

Cell-specific maximum uptake rates $\left(\mu \mathrm{mol} \mathrm{N}\right.$ cell $^{-1}$ $\mathrm{h}^{-1}$ ) were estimated from:

$$
v_{\max (\text { cell })}=v_{\max } \times \mathrm{PN} / n
$$

where $\mathrm{PN}$ is the estimated nitrogen biomass ( $\mu$ mol $\mathrm{N}$ $\mathrm{l}^{-1}$ ) of the dominant species (= total $\mathrm{PN} \times \%$ dominance) and $n$ is the cell concentration of the dominant species (cells $\mathrm{l}^{-1}$ ). The dominance of the species of interest was never $100 \%$; therefore, these conversions to cellular $v_{\max }$ are only estimates. Given the high proportion of the dominant species, we consider our calculations to be reasonable estimates that will allow us to make some inferences on the effect of cell size.
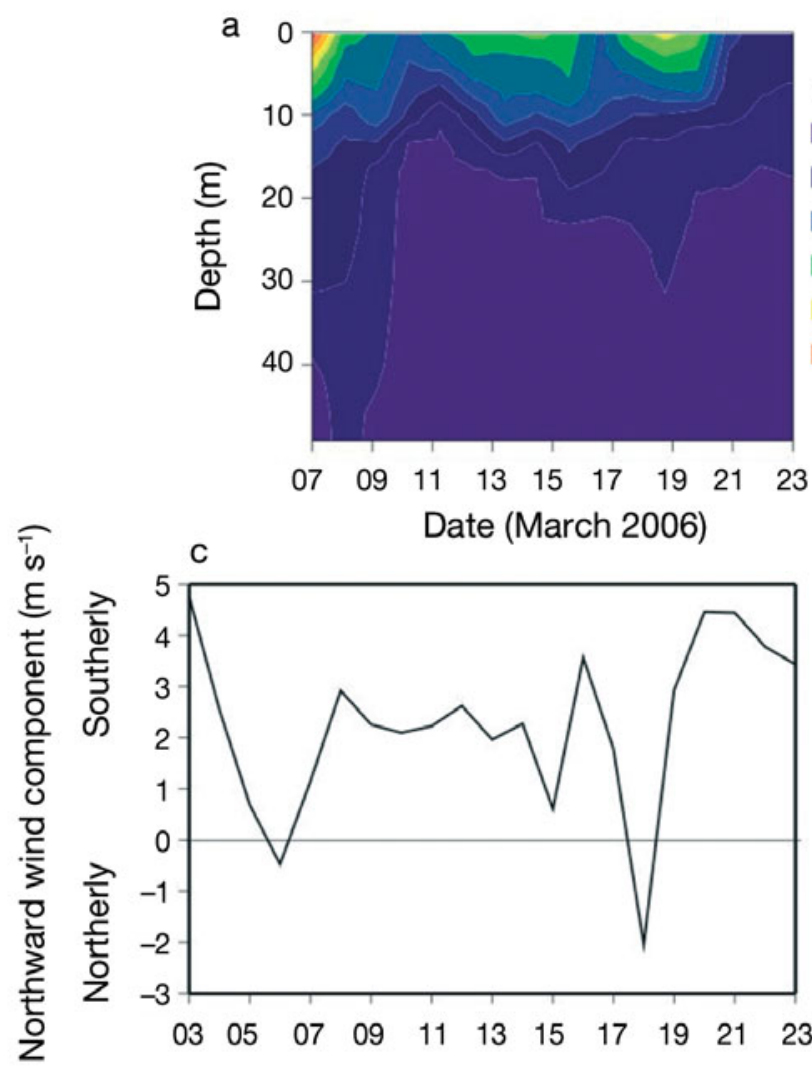

March 2006

\section{RESULTS}

\section{Hydrographic conditions}

Temperatures in both years fluctuated $\left(\sim 11\right.$ to $\left.17^{\circ} \mathrm{C}\right)$ as cold (11 to $12^{\circ} \mathrm{C}$ ) upwelling pulses alternated with warmer $\left(14\right.$ to $17^{\circ} \mathrm{C}$ ) relaxation/downwelling cycles.

In 2006, the sampling period was characterised on 3 occasions by surface warming (to $16^{\circ} \mathrm{C}$ on the first occasion, then $14^{\circ} \mathrm{C}$ ), with a thermocline apparent at 5 to $10 \mathrm{~m}$ depth (Fig. 2a). In between these periods, upwelling pulses introduced colder $\left(11\right.$ to $\left.12^{\circ} \mathrm{C}\right)$ water to the surface and the water column was well mixed. Strong southerly winds corresponded to upwelling events and northerly or weaker southerly winds were concurrent with downwelling and stratification (Fig. 2c). Most of the sampling period was characterised by southerly winds, with the exception of 18 to 19 March. Southerly winds were strongest immediately after this period, when water temperatures were lowest $\left(<11^{\circ} \mathrm{C}\right)$ and the water column was very well mixed.

In 2007 , recently upwelled water $\left(\sim 11^{\circ} \mathrm{C}\right)$ was present at the surface at the start of the survey. Northerly winds prevailed until 23 March, allowing surface tem-
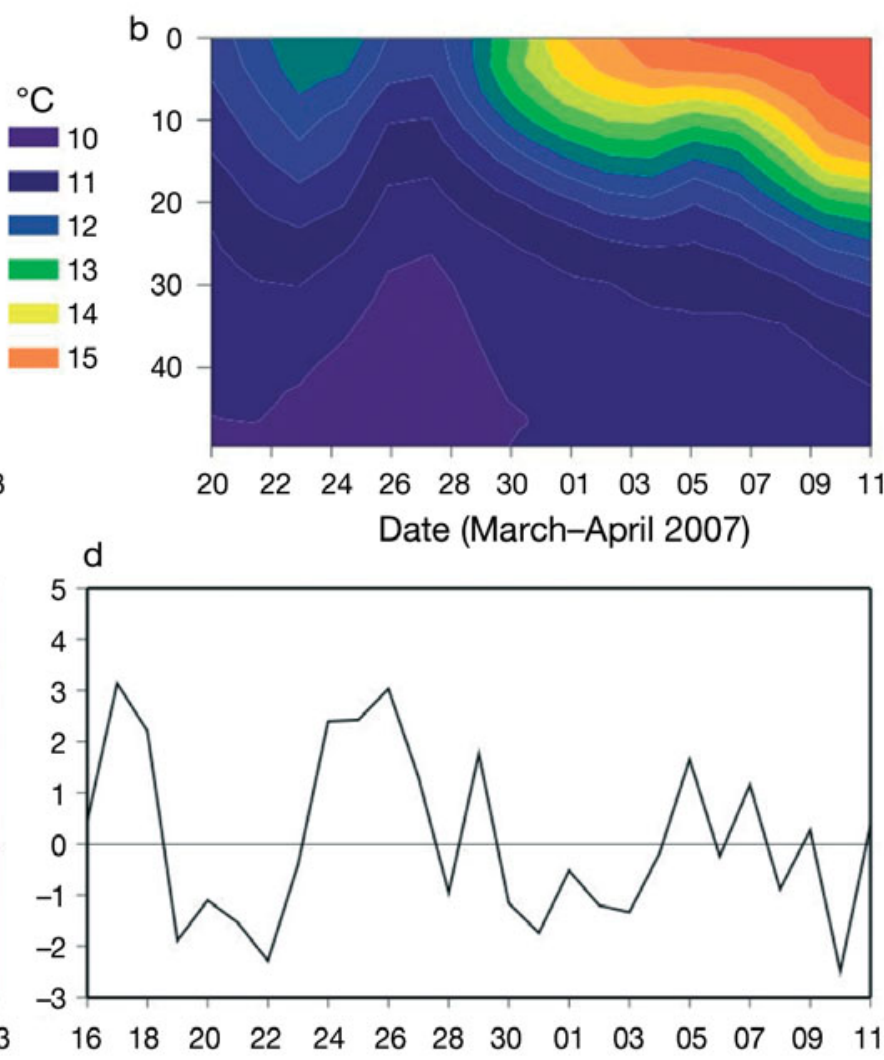

March-April 2007

Fig. 2. Temperature contour plots obtained from daily CTD casts in (a) 2006 and (b) 2007, and daily averaged northward wind components in (c) 2006 and (d) 2007 
peratures to warm to $14^{\circ} \mathrm{C}$ before wind reversal caused another pulse of upwelling to decrease surface temperatures to $11^{\circ} \mathrm{C}$ (Fig. 2b). Northerly winds then prevailed for most of the remaining period (Fig. $2 \mathrm{~d}$ ), and the water column became strongly stratified with surface temperatures increasing from 12 to $17^{\circ} \mathrm{C}$ over $\sim 8 \mathrm{~d}$ and remaining between 16 and $17^{\circ} \mathrm{C}$ thereafter.

\section{Nutrients}

Similar patterns were observed in both years, with surface nutrients fluctuating between high concentrations (17 to $25 \mu \mathrm{M} \mathrm{NO}_{3}{ }^{-}, 17$ to $49 \mu \mathrm{M} \mathrm{Si}, 2$ to $3 \mu \mathrm{M}$ $\mathrm{PO}_{4}{ }^{3-}$ ) during the upwelling periods and very low concentrations $\left(<0.8 \mu \mathrm{M} \mathrm{NO}_{3}{ }^{-},<4.0 \mu \mathrm{M} \mathrm{Si},<1.2 \mu \mathrm{M} \mathrm{PO}_{4}{ }^{3-}\right)$ during the stratified periods (Fig. 3). Overall, $\mathrm{NO}_{3}{ }^{-}$, $\mathrm{PO}_{4}{ }^{3-}$ and $\mathrm{Si}$ concentrations were significantly higher (119, 75 and 45\%, respectively) in 2006 than in 2007 (Student's $t$-test for $\mathrm{NO}_{3}{ }^{-}$and $\mathrm{PO}_{4}{ }^{3-}$, Mann-Whitney $U$ test for $\mathrm{Si}, \mathrm{p}<0.01)$. On the other hand, $\mathrm{NH}_{4}{ }^{+}$concentrations were, on average, $74 \%$ higher in 2007 than in 2006, although this difference was due to the presence of a few very high concentrations in 2007 and was not statistically significant. On average, urea concentrations were similar in both years.

$\mathrm{NH}_{4}{ }^{+}$concentrations ranged from 0.1 to $1.5 \mu \mathrm{M}$ at the surface and from 0.3 to $1.7 \mu \mathrm{M}$ at the subsurface in 2006 (Fig. 3e,g), and from 0.1 to $4.2 \mu \mathrm{M}$ at $0 \mathrm{~m}$ and from 0.05 to $4.4 \mu \mathrm{M}$ at $5 \mathrm{~m}$ in 2007 (Fig. 3f,h). Concentrations were significantly higher $(52 \%)$ at the subsurface than at the surface in 2006 (paired $t$-test); however, the difference $(15 \%)$ was not significant in 2007.

Urea concentrations ranged from 0.2 to $1.0 \mu \mathrm{mol} \mathrm{N}$ $\mathrm{l}^{-1}$ at the surface and from 0.5 to $3.1 \mu \mathrm{mol} \mathrm{N} \mathrm{^{-1 }}$ in the subsurface in 2006 (Fig. 3e,g) and from 0.2 to $1.3 \mu \mathrm{mol}$ $\mathrm{N} \mathrm{l}^{-1}$ at the surface and from 0.4 to $3.7 \mu \mathrm{mol} \mathrm{N}{ }^{-1}$ in the subsurface in 2007 (Fig. 3f,h). Concentrations in both years were significantly higher (250 and $254 \%$, respectively) at the subsurface than at the surface (paired $t$-test, $\mathrm{p}<0.01)$.

\section{Chl a}

In both years, chl a usually displayed a maximum at 5 to $10 \mathrm{~m}$ depth, although the highest concentration of $57 \mu \mathrm{g} \mathrm{l}^{-1}$ in 2006 was measured at the surface (Fig. $4 \mathrm{a}, \mathrm{b}$ ). Maximum concentrations at $5 \mathrm{~m}$ were $44 \mu \mathrm{g}$ $\mathrm{l}^{-1}$ in 2006 and $64 \mu \mathrm{g} \mathrm{l}^{-1}$ in 2007.

Generally, chl a concentrations increased during periods of stratification following wind reversal (Figs. 2 \& 4a,b). However, in April 2007, the persistence of warm, stratified conditions led to a decline in chl $a$, which remained at $<5 \mu \mathrm{g} \mathrm{l}^{-1}$ for the last $10 \mathrm{~d}$ of the sur- vey (Fig. 4b). In 2006, stratification did not persist for longer than $4 \mathrm{~d}$ and chl a concentrations were always $>8 \mathrm{~g} \mathrm{l}^{-1}$, whereas in 2007, concentrations dropped occasionally below $1 \mu \mathrm{g} \mathrm{l}^{-1}$. Overall, chl a concentrations were significantly higher (98\%) in 2006 than in 2007 (Student's $t$-test, $\mathrm{p}<0.01$ ).

\section{Phytoplankton community structure}

In 2006, diatoms were always dominant, representing 96 to $100 \%$ of the total phytoplankton numerical abundance (Fig. 4c), whereas in 2007, dinoflagellate dominance $(65 \%$ on 21 March, $100 \%$ on 4 to 5 and on 8 to 10 April), alternated with diatom dominance (71 to $100 \%$ on 20 and 22 to 25 March, on 29 March to 3 April and 6 to 7 April) (Fig. 4d). Cluster analysis performed on both years' data combined revealed that, at the $60 \%$ similarity level, all 2006 stations clustered together, whereas the 2007 stations were divided into 4 clusters or assemblage types (Fig. 5).

In 2006, the dominant diatom species were Pseudonitzschia (up to $85 \%$ ) and Chaetoceros spp. (up to $41 \%$ ) (Fig. 4e), and these 2 taxa together were responsible for $96 \%$ of similarity between the 2006 stations (assemblage Type V; Table 1). Pseudo-nitzschia 'Species 1' was the most abundant, representing 45 to $93 \%$ of the total Pseudo-nitzschia concentrations, followed by $P$. australis with 0 to $50 \%$. The contribution of dinoflagellates was low (maximum $4 \%$ of the total cell concentration on $20 \mathrm{March}$ ), and these were composed mainly of Prorocentrum micans, P. triestinum and Scrippsiella trochoidea (Fig. 4g).

In 2007, the dominant diatom species were Skeletonema costatum (28 to $85 \%$ ), Chaetoceros spp. (8 to $93 \%$ ) and Pseudo-nitzschia (2 to $30 \%$ ) (Fig. 4f). These 3 taxa were collectively responsible for $76 \%$ similarity within assemblage Type III, whereas Pseudo-nitzschia spp. and Chaetoceros spp. alone were responsible for $83 \%$ similarity within Type IV (Table 1). The dominant dinoflagellate species was Alexandrium catenella at the start of the survey (48\% cell concentration, $77 \%$ biomass on 21 March); however, the cluster that was characterised by A. catenella (Type I) was also defined by the presence of $S$. costatum (Table 1). Gymnodinium spp. were dominant on 4 to 5 and on 9 to 10 April (92 to $100 \%$ total cell numbers), and these stations formed assemblage Type II together with 8 April, which was numerically co-dominated by Dinophysis acuminata (44\%) and Gymnodinium sp. (54\%) (Fig. 4h), although in terms of biomass it was dominated by $D$. acuminata $(91 \%)$.

The Shannon diversity index $\left(H^{\prime}\right)$ was broadly related to the upwelling/relaxation cycles, with the highest values occurring in nutrient-rich, newly upwelled 

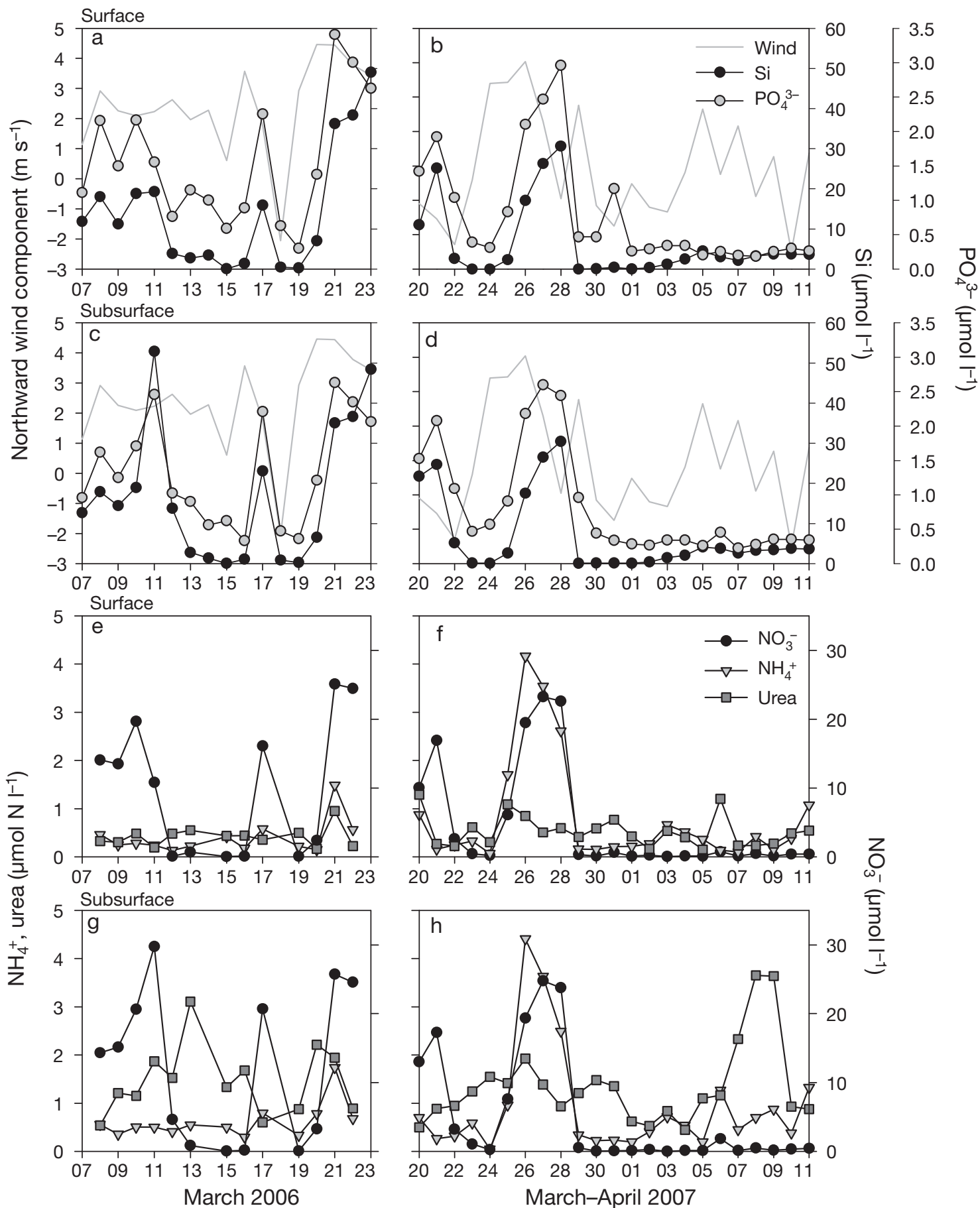

$\mathrm{c}_{\mathrm{\omega}}$
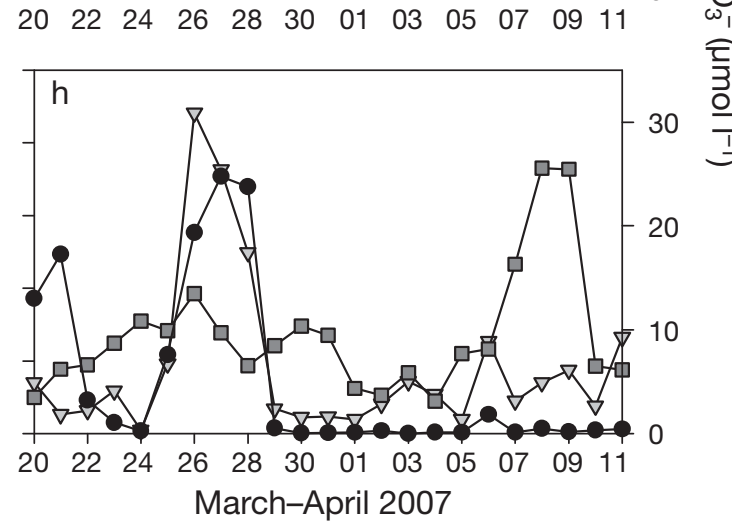

Fig. 3. Northward wind components and concentrations of $\mathrm{Si}$ and $\mathrm{PO}_{4}{ }^{3-}$ at the surface in (a) 2006 and (b) 2007 and in the subsurface in (c) 2006 and (d) 2007; concentrations of $\mathrm{NO}_{3}{ }^{-}, \mathrm{NH}_{4}{ }^{+}$and urea at the surface in (e) 2006 and (f) 2007 and in the subsurface in (g) 2006 and (h) 2007

waters (assemblage Types I, III \& V) and the lowest occurring in nutrient-poor, stratified waters (Table 1).

Type I assemblages were associated with the lowest average temperatures, which were 9 to $29 \%$ lower than for the other types (these differences were significant in all cases except with Type V, as shown by either Student's $t$-test or Mann-Whitney's $U$-test), and with aver- age $\mathrm{NO}_{3}{ }^{-}$concentrations up to 2 orders of magnitude higher than those of the other types (Table 1). Type II was associated with the warmest temperatures and the lowest $\mathrm{NO}_{3}{ }^{-}$concentrations (significantly different from all other types except IV). Types III and V occurred at intermediate temperatures and $\mathrm{NO}_{3}{ }^{-}$concentrations (Table 1). 

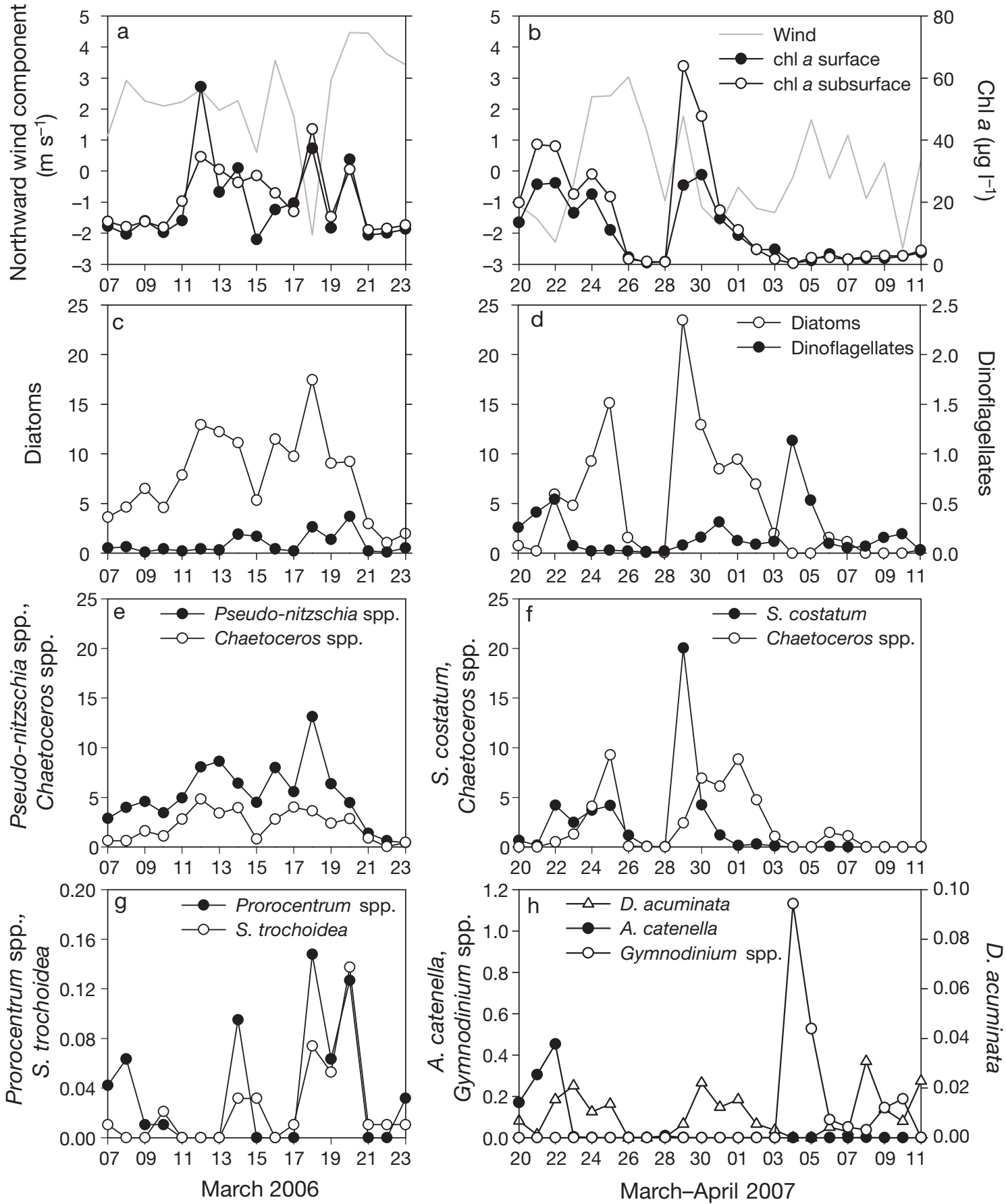

Fig. 4. Chlorophyll a (chl a) concentrations and northward wind components in (a) 2006 and (b) 2007; total diatom and dinoflagellate concentrations $\left(\times 10^{6}\right.$ cells l$\left.^{-1}\right)$ in (c) 2006 and (d) 2007; concentrations $\left(\times 10^{6}\right.$ cells l$^{-1}$ ) of the main diatom species in (e) 2006 and (f) 2007 and of the main dinoflagellate species in (g) 2006 and (h) 2007. Full taxonomic names: see Table 1

\section{Nutrient uptake}

Rates of nutrient uptake broadly followed the upwelling/relaxation cycles, where absolute nitrogen

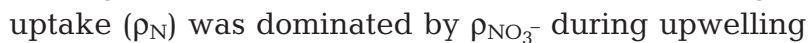
and by $\rho_{\mathrm{NH}_{4}}{ }^{+}$and $\rho_{\text {urea }}$ during stratified, $\mathrm{NO}_{3}{ }^{-}$-depleted periods. On average, $\rho_{\mathrm{NO}_{3}}-$ was significantly higher $(142 \%)$ in 2006 than in 2007, whereas $\rho_{\mathrm{NH}_{4}}{ }^{+}$was significantly lower $(17 \%, \mathrm{p}<0.01)$.

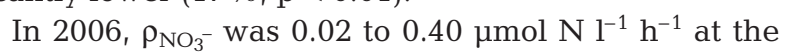

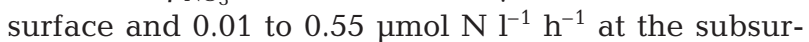
face, whereas $\rho_{\mathrm{NH}_{4}}$ was 0.04 to 0.15 at $0 \mathrm{~m}$ and 0.03 to 


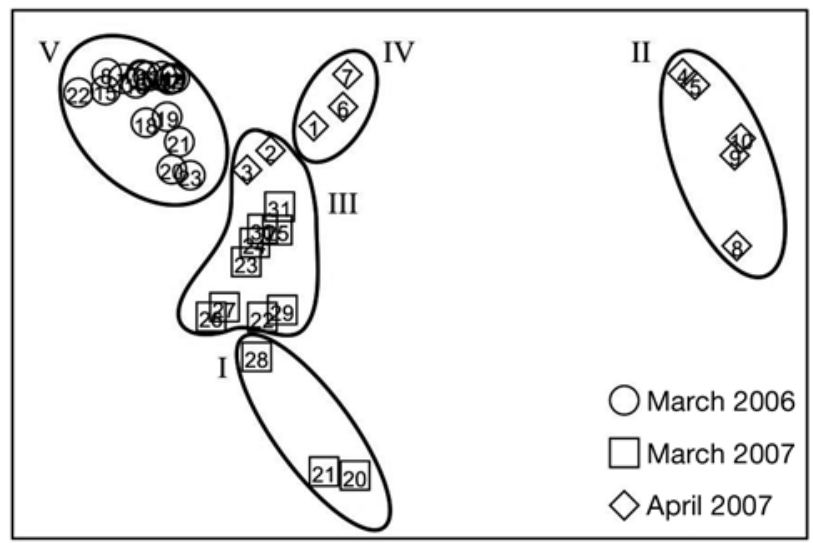

Fig. 5. MDS plot for months in 2006 and 2007 combined. Clusters identified at the $60 \%$ similarity level are circled and labelled (I to V) as in Table 1. Symbol shape represents month and year and labels represent day of the month

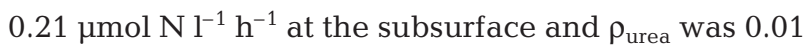

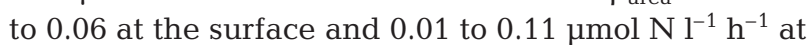
the subsurface (Fig. 6a, c). Overall, $\rho_{\mathrm{NO}_{3}{ }^{-}}$was significantly higher than $\rho_{\mathrm{NH}_{4}}(112 \%)$ and $\rho_{\text {urea }}(278 \%)$ at both depths, and $\rho_{\mathrm{NH}_{4}}+$ was significantly (79\%) higher than $\rho_{\text {urea }}$ (paired $t$-test, $\mathrm{p}<0.01$ ).

In 2007, $\rho_{\mathrm{NO}_{3}}-$ was particularly high for the Alexandrium catenella-dominated assemblage on 21 March

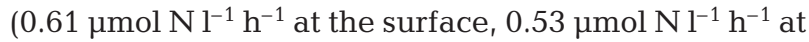
the subsurface), but was generally low for the rest of

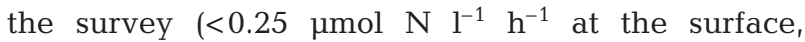

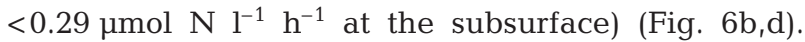

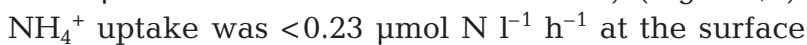

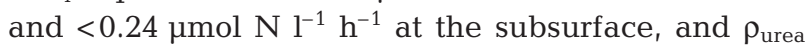

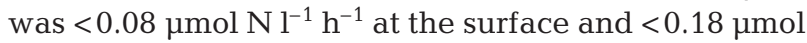
$\mathrm{N} \mathrm{l}^{-1} \mathrm{~h}^{-1}$ at the subsurface (Fig. 6b,d). Overall, $\rho_{\mathrm{NH}_{4}{ }^{+}}$ was significantly higher $(137 \%)$ than $\rho_{\text {urea }}$ at both depths (paired $t$-test, $\mathrm{p}<0.001$ ).

The alternating dominance of new $\left(\mathrm{NO}_{3}{ }^{-}\right)$and regenerated $\left(\mathrm{NH}_{4}{ }^{+}\right.$and urea) nitrogen uptake during the upwelling/downwelling cycles was reflected in the variable $f$-ratios $\left[=\rho_{\mathrm{NO}_{3}-} /\left(\rho_{\mathrm{NO}_{3}{ }^{-}}+\rho_{\mathrm{NH}_{4}}{ }^{+}+\rho_{\text {urea }}\right)\right.$ (Eppley $\&$ Peterson 1979)] of 0.11 to 0.84 at the surface and 0.10 to 0.80 at the subsurface in 2006 (Fig. 6e) and 0.06 to 0.87 at the surface and 0.03 to 0.79 at the subsurface in 2007 (Fig. 6f). Overall, $f$-ratios were significantly higher in 2006 than in 2007 (Student's $t$-test, p < 0.01). There was a significant linear correlation with wind (previous day northward component) at both depths in 2006 ( $\mathrm{n}=26, \mathrm{p}<0.01$ ) and in 2007, after removal of 21 to 22 March, which represented the unusual combination of high $f$-ratio and northerly wind $(\mathrm{n}=28)$ (Fig. 7).

Some significant differences in $\rho_{\mathrm{N}}$ (as shown by Student's $t$-test or Mann-Whitney's $U$-test as appropriate) were observed between the different assemblage types. Type I had the lowest average $\rho_{\mathrm{NH}_{4}}$ (2- to 3 - fold lower than other types) and the highest $\rho_{\mathrm{NO}_{3}-}$ (2- to 30 -fold higher), although with only 2 measurements in that group it was not possible to prove the significance of these differences. Type II assemblages displayed on average 2.5-fold higher $\rho_{\mathrm{NH}_{4}}$ than Type I and significantly lower $\rho_{\mathrm{NO}_{3}}{ }^{-}$than Types III, IV and V (3- to 18fold). Consequently, Type II assemblages displayed significantly (3- to 7 -fold) lower $f$-ratios than Assemblage Types III and V. Type III assemblages displayed $50 \%$ lower $f$-ratios than did Type V.

\section{Nutrient uptake kinetics}

Maximum specific uptake rates $\left(v_{\max }\right)$ for both Pseudonitzschia- and Dinophysis acuminata-dominated assemblages were higher for $\mathrm{NH}_{4}{ }^{+}$than for $\mathrm{NO}_{3}{ }^{-}(21 \%$ and 4-fold, respectively) (Fig. 8, Table 3). For Pseudonitzschia, the estimate of $v_{\max }$ for urea derived from averaging urea at the 4 highest (saturating) concentrations was $\sim 3$-fold lower than $v_{\text {max }}$ for $\mathrm{NH}_{4}{ }^{+}$and $\mathrm{NO}_{3}{ }^{-}$. $D$. acuminata also displayed lower (2-fold) $v_{\max }$ for urea than for $\mathrm{NH}_{4}{ }^{+}$, but 2-fold higher than for $\mathrm{NO}_{3}{ }^{-}$. All 3 species displayed similar $v_{\text {max }}$ for $\mathrm{NH}_{4}{ }^{+}\left(13.9 \times 10^{-3}\right.$ to $18.0 \times$ $10^{-3} \mathrm{~h}^{-1}$ ), and Pseudo-nitzschia displayed a 5-fold higher $v_{\text {max }}$ for $\mathrm{NO}_{3}{ }^{-}$than $D$. acuminata. On the other hand, $D$. acuminata displayed the highest $v_{\max }$ for urea, 27 and $77 \%$ higher than for Pseudo-nitzschia and A. catenella, respectively.

On a per cell basis, $v_{\max }$ increased with size, from Alexandrium catenella to Dinophysis acuminata for $\mathrm{NH}_{4}{ }^{+}$and urea, and was higher in D. acuminata than in Pseudo-nitzschia for $\mathrm{NO}_{3}^{-}$(Table 3).

Half-saturation constants $\left(K_{\mathrm{s}}\right)$ were lowest for Dinophysis acuminata for all 3 nutrients and for urea in

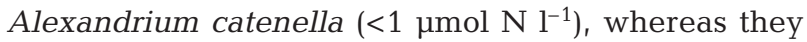
were $>1 \mu \mathrm{mol} \mathrm{N} \mathrm{l}{ }^{-1}$ for Pseudo-nitzschia and $\mathrm{NH}_{4}{ }^{+}$in A. catenella (Table 3 ). Furthermore, $K_{\mathrm{s}}$ was higher for $\mathrm{NH}_{4}{ }^{+}$than for $\mathrm{NO}_{3}{ }^{-}$in Pseudo-nitzschia, whereas the opposite was observed for $D$. acuminata; $K_{\mathrm{s}}$ was lower for urea than for $\mathrm{NH}_{4}{ }^{+}$in $A$. catenella, whereas the opposite was observed in $D$. acuminata. These values are given for comparison with earlier studies that did not report $\alpha$ (the initial slope of the curve); however, the present study focussed on $\alpha$-values as a measure of affinity.

Pseudo-nitzschia and Alexandrium catenella displayed little variability in $\alpha$ between $\mathrm{N}$ sources. On a nitrogen basis, $\alpha$ for $\mathrm{NH}_{4}{ }^{+}$was $\sim 2$-fold higher for Pseudo-nitzschia than for $A$. catenella, but on a per cell basis, $\alpha$ was 1 order of magnitude higher for A. catenella (Table 3 ). The highest $\alpha$-value was measured for $\mathrm{NH}_{4}{ }^{+}$in Dinophysis acuminata and, on a per cell basis, the highest $\alpha$-values were those measured for all nitrogen sources in D. acuminata. 

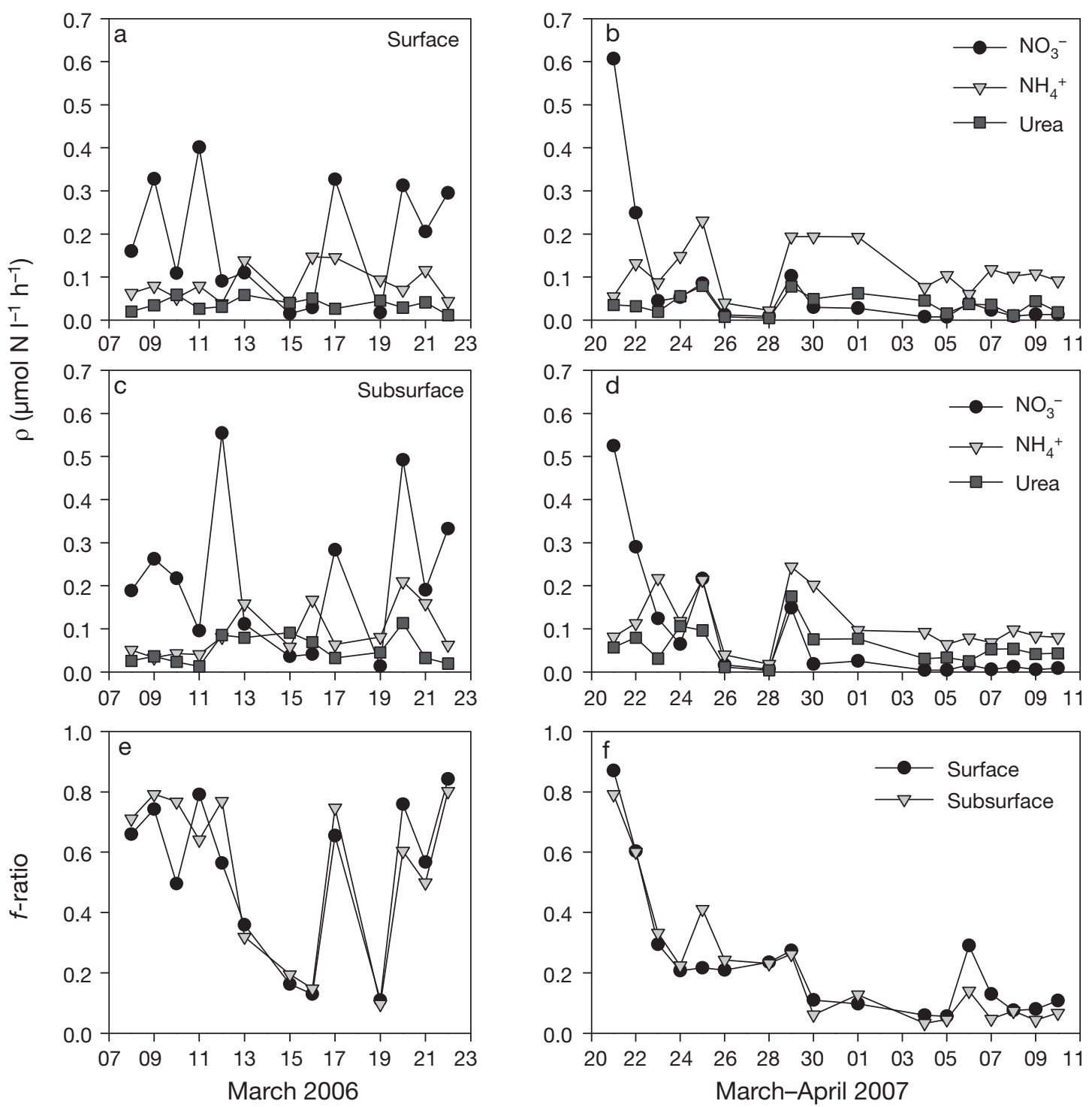

Fig. 6. Surface uptake rates of $\mathrm{NH}_{4}{ }^{+}, \mathrm{NO}_{3}{ }^{-}$and urea in (a) 2006 and (b) 2007; subsurface uptake rates in (c) 2006 and (d) 2007 ; and $f$-ratios at both depths in (e) 2006 and (f) 2007

\section{DISCUSSION}

Although the occurrence of HABs along the west coast of South Africa is clearly linked to wind forcing and water column stability (Pitcher et al. 1998, Probyn et al. 2000, Pitcher \& Nelson 2006, Fawcett et al. 2007), little is known about the nitrogen nutrition of HAB species during upwelling/quiescent cycles.

The different assemblage types identified by cluster analysis could, to a certain extent, be linked with nutrient regime. For example, Type I (Alexandrium catenella/Skeletonema costatum) was associated with recently upwelled water, i.e. lower temperatures and generally higher $\mathrm{NO}_{3}{ }^{-}$concentrations. Although Type $\mathrm{V}$ (Pseudo-nitzschia) assemblages appeared to be favoured by high $\mathrm{NO}_{3}{ }^{-}$concentrations, they were still able to sustain their growth by utilising recycled nitrogen when $\mathrm{NO}_{3}{ }^{-}$became limiting and occurred at temperatures ranging from 11 to $14^{\circ} \mathrm{C}$. Types II (Gymnodinium spp./ Dinophysis acuminata) and IV (Chaetoceros spp.), on the other hand, were associated with warm, stratified conditions, low $\mathrm{NO}_{3}{ }^{-}$concentrations and low $f$-ratios. Type III (mixed diatoms) was present under intermediate temperature and $\mathrm{NO}_{3}{ }^{-}$conditions.

\section{Alexandrium catenella}

The Alexandrium catenella bloom was present before the start of our survey in 2007; therefore, we do not 


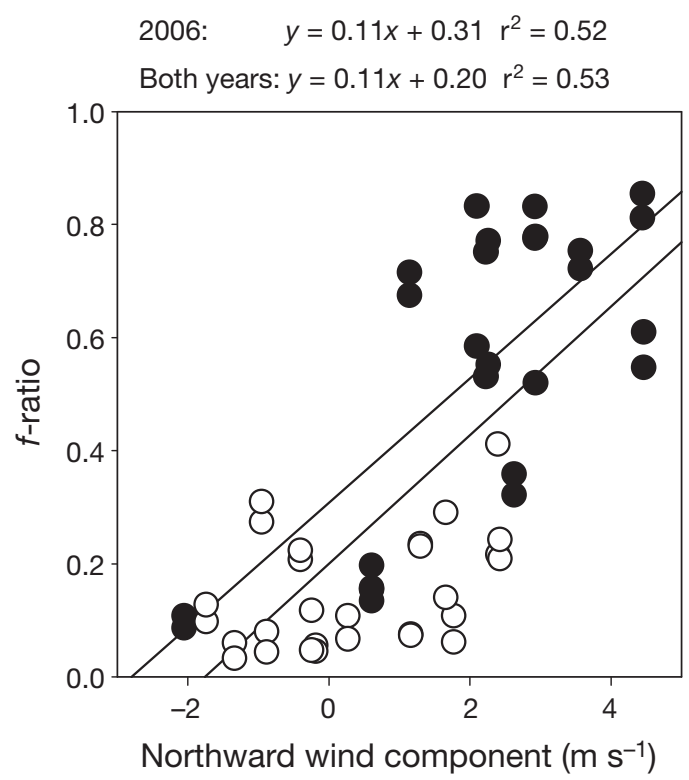

Fig. 7. $f$-ratio versus northward wind component in 2006 ( and 2007 (O). Data are from both incubation depths. Linear correlations were significant in 2006 and for both years combined (but not in 2007 alone)

know under which conditions it was initiated. However,

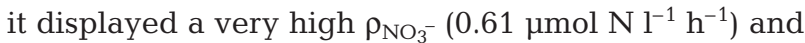
$f$-ratio (0.87), and the concentration of $A$. catenella cells dropped rapidly when $\mathrm{NO}_{3}{ }^{-}$became depleted, indicating that high $\mathrm{NO}_{3}{ }^{-}$concentrations would have been required to sustain this bloom concentration. Also, the second pulse of upwelling (25 March) reintroduced A. catenella cells, confirming the link between upwelling/high $\mathrm{NO}_{3}{ }^{-}$and the presence of A. catenella. Although it became more abundant over the next $3 \mathrm{~d}$, it then disappeared from the community, possibly because of competitive exclusion by diatoms but most likely due to alongshore (and to a lesser extent onshore) advection and decreasing $\mathrm{NO}_{3}{ }^{-}$concentrations. A. catenella is known to form cysts in the Lambert's Bay area (Joyce \& Pitcher 2004), and encystment can occur in response to nutrient starvation (Anderson et al. 1984), so its disappearance could be attributable to encystment and sinking in response to nutrient depletion. Nitrate uptake by the $A$. catenella bloom (measured on 21 March 2007) was the highest measured in both years, higher than the maximum measured rate in the Benguela for the period from 1983 to 1991 (Probyn

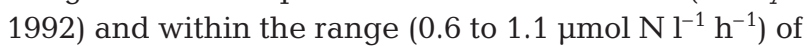
theoretical maximum uptake rates calculated by Probyn (1992). Nitrate uptake was also higher than maximum values measured in the Californian, Peruvian and northwestern African upwelling systems (Dugdale et al. 1990). However, our maximum $\rho_{\mathrm{NO}_{3}-}$ was only $\sim 17 \%$ of that measured in the Ría de Ferrol within the Iberian upwelling system (Bode et al. 2005).

Studies of Alexandrium catenella blooms and cultures have yielded contradictory results with respect to their nitrogen requirements. For example, very high $\mathrm{NO}_{3}{ }^{-}$requirements $(>880 \mu \mathrm{M}$ ) (Siu et al. 1997) and high $K_{\mathrm{s}}$ for growth (3.3 to $7.7 \mu \mathrm{M}$ ) (Matsuda et al. 1999) have been measured in cultures of $A$. catenella. In the Mediterranean, blooms were associated with high $\mathrm{NO}_{3}{ }^{-}$and $\mathrm{NH}_{4}{ }^{+}$concentrations on the northeast Spanish coast (Bravo et al. 2008), whereas $\mathrm{NH}_{4}{ }^{+}$and urea were the main nitrogen sources fuelling a bloom in the Thau Lagoon on the French coast (Collos et al. 2007). A similar dichotomy exists for A. minutum: a bloom in Cape Town harbour displayed extremely high $\rho_{\mathrm{NH}_{4}}{ }^{+}$

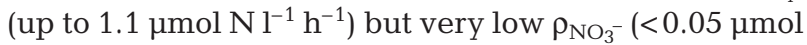
$\mathrm{N}^{-1} \mathrm{~h}^{-1}$ ) (Pitcher et al. 2007), whereas the $\mathrm{NO}_{3}^{-}$ requirement of an $A$. minutum bloom in the Penze Estuary (northwest France) was calculated at $184 \mu \mathrm{M}$, with an $\mathrm{NH}_{4}{ }^{+}$requirement of only $25 \mu \mathrm{M}$ (Maguer et al. 2004).
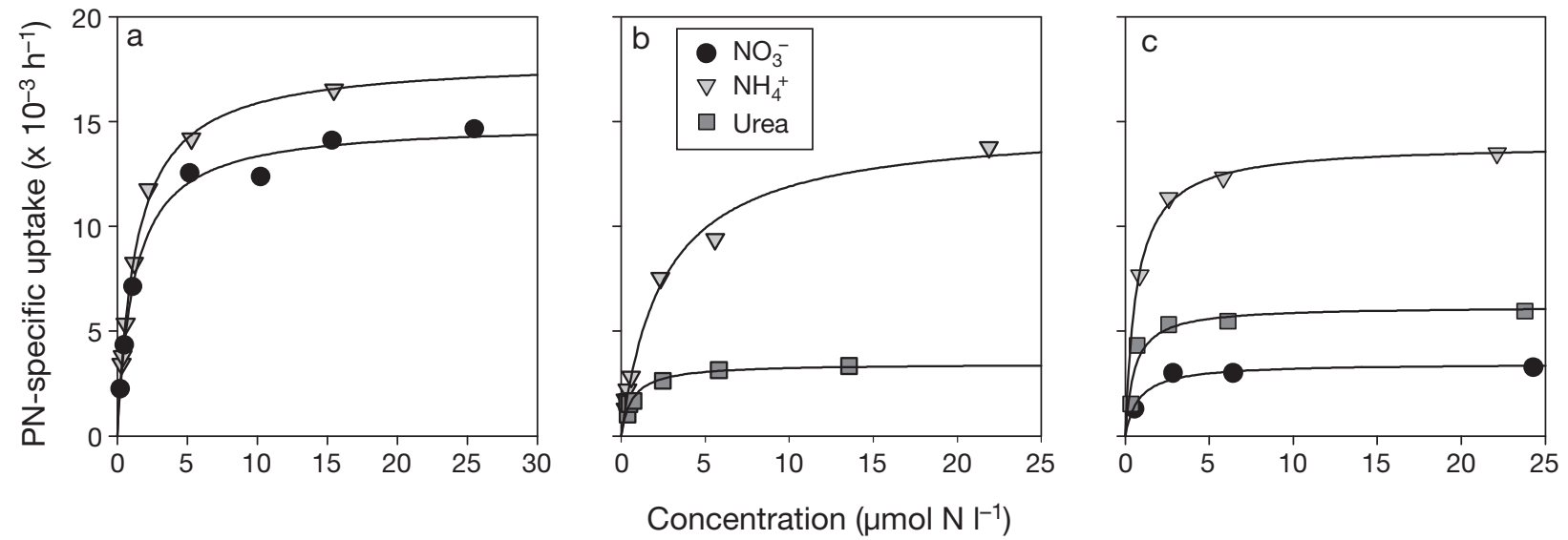

Fig. 8. Nutrient uptake versus concentration data fitted to the Michaelis-Menten equation using iterative, non-linear regression. Experiments were performed on (a) 16 March 2006, (b) 21 March 2007 and (c) 8 April 2007 on assemblages dominated by (a) Pseudo-nitzschia, (b) Alexandrium catenella and (c) Dinophysis acuminata. PN: particulate nitrogen 
Measurements of $\rho_{\mathrm{N}}$ in the field provide limited information on nutritional preference because in upwelling systems, $\rho_{\mathrm{NO}_{3}-}$ increases as a 'shift-up' response to increased $\mathrm{NO}_{3}{ }^{-}$concentrations supplied by upwelling (Dugdale et al. 1990, 2006). This is demonstrated in our study by the significant correlation between $f$-ratios and wind direction, used as an indicator of upwelling, hence $\mathrm{NO}_{3}{ }^{-}$concentration (Fig. 7). Furthermore, the relative preference index (RPI, McCarthy et al. 1977) is also biased by ambient concentrations, particularly in upwelling systems where $\mathrm{NO}_{3}{ }^{-}$can be much more abundant than $\mathrm{NH}_{4}{ }^{+}$(Stolte \& Riegman 1996). The parameters of uptake kinetics can provide valuable information on the nutritional preferences of a given species (Dugdale 1967, Dortch 1990) and the potential outcome of interspecific competition for nutrients (Eppley et al. 1969), although they too can vary in response to nitrogen starvation (MacIsaac \& Dugdale 1969, Collos 1980) and to elevated ambient nitrogen concentrations (Caperon \& Meyer 1972, Collos et al. 2005).

In our study, $v_{\max }$ was at least $17 \%$ higher for $\mathrm{NO}_{3}{ }^{-}$ than for $\mathrm{NH}_{4}{ }^{+}$(based on $\mathrm{v}_{\mathrm{NO}_{3}^{-}}$measured at ambient concentration) and 5-fold higher than for urea, whereas $\alpha$ for $\mathrm{NH}_{4}{ }^{+}$and urea were low, indicating that Alexandrium catenella was a poor competitor for those substrates at low concentrations $\left(<K_{\mathrm{s}}\right)$ measured during the bloom. In the Thau Lagoon, on the other hand, A. catenella displayed a preference for $\mathrm{NH}_{4}{ }^{+}$, as shown by higher $v_{\max }$ and $\alpha$ for $\mathrm{NH}_{4}{ }^{+}$than for $\mathrm{NO}_{3}{ }^{-}$(Collos et al. 2004). Although $v_{\max }$ in our study was 4 - and 17 -fold lower than that in the Thau for $\mathrm{NH}_{4}{ }^{+}$and urea, respectively, $K_{\mathrm{s}}$ was also lower and as a result $\alpha$ was similar for $\mathrm{NH}_{4}{ }^{+}$and 4 -fold higher for urea in our study, indicating that $A$. catenella was a relatively poor competitor for low ambient nitrogen in both regions (including $\mathrm{NO}_{3}{ }^{-}$in the Thau). The lower $v_{\max }$ and $K_{\mathrm{s}}$ for $\mathrm{NH}_{4}{ }^{+}$and urea in the Benguela could be a result of natural selection for low-nutrient-adapted cell lines (Doyle 1975) in an environment where $\mathrm{NH}_{4}{ }^{+}$and urea concentrations are often $<1 \mu \mathrm{mol} \mathrm{N}{ }^{-1}$, whereas they can be as high as 8 and $4 \mu \mathrm{mol} \mathrm{N}{ }^{-1}$ in the Thau (Collos et al. 2007).

Of the 5 studies carried out on HAB dinoflagellates in the upwelling systems presented in Table 4 (Kudela \& Cochlan 2000, Kudela et al. 2008a,b), Alexandrium catenella in the present study was the only one that expressed a preference for $\mathrm{NO}_{3}{ }^{-}$over $\mathrm{NH}_{4}{ }^{+}$, and its $v_{\max }$ for $\mathrm{NO}_{3}{ }^{-}$was higher than those of the other species. The $v_{\max }$ of $A$. catenella for $\mathrm{NH}_{4}{ }^{+}$was similar to that of Akashiwo sanguinea, which was the highest out of the 6 studies, although its $\alpha$ value for $\mathrm{NH}_{4}{ }^{+}$was at the low end of the spectrum, indicating that it was a better competitor for $\mathrm{NH}_{4}{ }^{+}$at high concentrations. On the other hand, $A$. catenella displayed low values for both $v_{\max }$ and $\alpha$ for urea, indicating that it was a poor

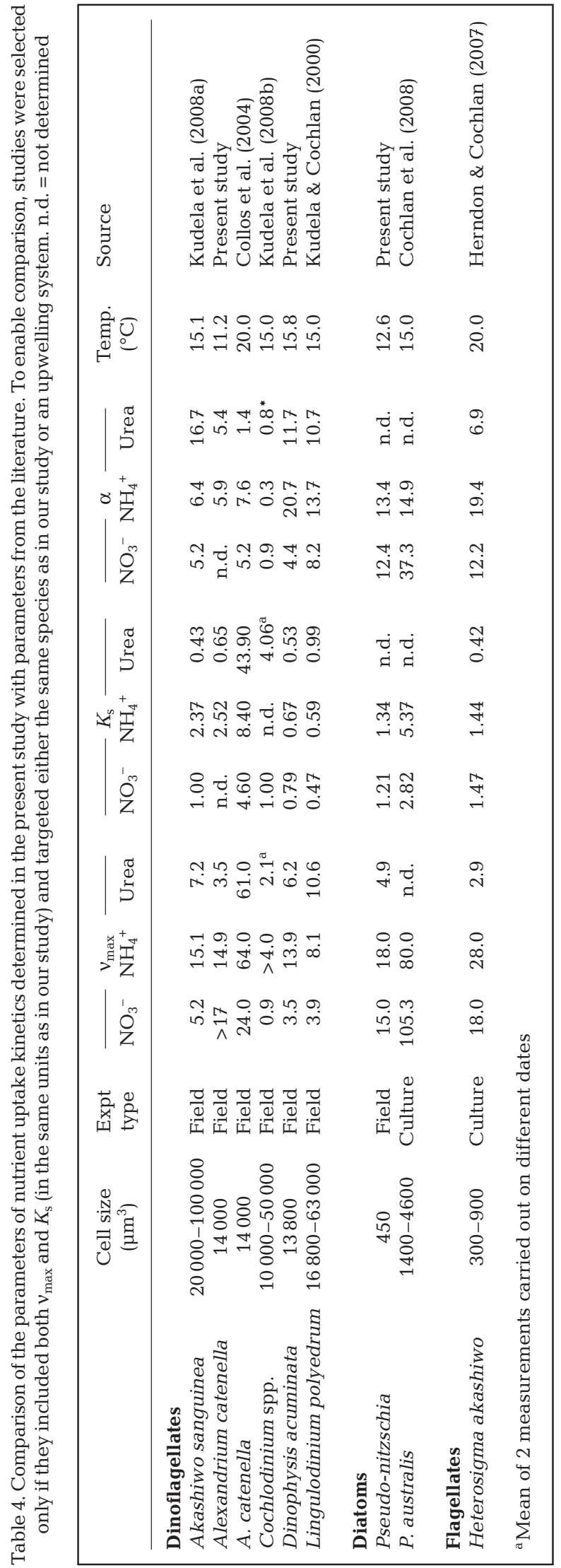


competitor for urea at both high and low concentrations. Higher $v_{\text {max }}$ for $\mathrm{NH}_{4}{ }^{+}$and similar (if not lower) $v_{\text {max }}$ for $\mathrm{NO}_{3}{ }^{-}$and urea were measured in cultures of the raphidophyte Heterosigma akashiwo isolated from the California upwelling system (Herndon \& Cochlan 2007) (Table 4). The higher $\alpha$ measured for $H$. akashiwo indicated that it was also a better competitor for $\mathrm{NH}_{4}{ }^{+}$at limiting concentrations, which is consistent with the hypothesis that small flagellates express a preference for $\mathrm{NH}_{4}{ }^{+}$(Glibert et al. 1982a, Probyn 1985). Overall, A. catenella in the present study displayed characteristics typically attributed to diatoms.

Nitrate concentrations in the other studies were low; therefore, the higher $v_{\max }$ for $\mathrm{NO}_{3}{ }^{-}$in the Benguela could be explained by acclimation to a higher ambient concentration, which is mediated by an increase in the number of uptake sites on a cell's surface (Caperon \& Meyer 1972).

Temperature can also influence variability in the uptake kinetics of $\mathrm{NH}_{4}{ }^{+}$and $\mathrm{NO}_{3}{ }^{-}$, whereby $v_{\text {max }}$ and $\alpha$ for $\mathrm{NH}_{4}{ }^{+}$are positively correlated with temperature and $\alpha$ for $\mathrm{NO}_{3}{ }^{-}$is negatively correlated with temperature (Lomas et al. 1996, Fan et al. 2003). The lower temperature in the Benguela compared to that in the other studies (Table 4) could contribute to lowering $v_{\text {max }}$ and $\alpha$ for $\mathrm{NH}_{4}{ }^{+}$; however, the large differences in $\alpha$ for urea were due to other factors, since urea uptake is thought to be independent of temperature (Fan et al. 2003). In the latter case, interspecific differences were probably the most significant.

\section{Pseudo-nitzschia}

Pseudo-nitzschia Species 1 was dominant throughout the 2006 survey and present in very high concentrations ( $>10^{6}$ cells $\mathrm{l}^{-1}$ except on the last $3 \mathrm{~d}$ ), whereas $P$. australis was less abundant, although reaching concentrations $>10^{6}$ cells $\mathrm{l}^{-1}$ on several occasions and representing up to $50 \%$ of the total Pseudo-nitzschia cell numbers when total concentrations were lowest. Upwelling-induced high $\mathrm{NO}_{3}^{-}$concentrations $(>10 \mu \mathrm{M})$

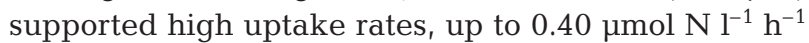
at the surface, with maximum uptake $~ 30 \%$ higher than that measured in Pseudo-nitzschia populations in the Juan de Fuca eddy (Washington coast, USA) (Marchetti et al. 2004). Highest cell concentrations were reached during periods of wind relaxation/reversal, during which $\mathrm{NO}_{3}^{-}$became depleted in the surface layer. Pseudo-nitzschia was able to maintain its population size $\left(5 \times 10^{6}\right.$ to $9 \times 10^{6}$ cells $\left.\mathrm{l}^{-1}\right)$ and to remain dominant despite the depletion of $\mathrm{NO}_{3}{ }^{-}$and $\mathrm{Si}$ and the increase in dinoflagellate abundance. This could be due to the lower cellular nitrogen requirements owing to its smaller cell size relative to that of dinoflagellates, as predicted by the positive correlation between the minimum cell-specific nitrogen quota and cell volume (Aksnes \& Egge 1991, Litchman et al. 2007). In addition, the ability to take up $\mathrm{NH}_{4}^{+}$(up to $0.15 \mu \mathrm{mol} \mathrm{N} \mathrm{^{-1 }}$ $\mathrm{h}^{-1}$ ) would have increased its competitive advantage when $\mathrm{NO}_{3}^{-}$became limiting.

PN-specific $v_{\text {max }}$ was higher for $\mathrm{NH}_{4}{ }^{+}$relative to both dinoflagellate species and for $\mathrm{NO}_{3}{ }^{-}$relative to Dinophysis acuminata, although, on a per-cell basis, $v_{\max }$ was lower relative to the dinoflagellate species due to its smaller cell size (Table 3), consistent with the $V_{\text {cell }}-v_{\max }$ relationship derived by Litchman et al. (2007). This trend of lower cell-specific but higher biomass-specific $v_{\max }$ seems to hold true for diatoms as a whole relative to dinoflagellates (Litchman et al. 2007). The higher biomass-specific $v_{\max }$ may be due to an increased number of smaller uptake sites per unit cell surface area (Caperon \& Meyer 1972, Aksnes \& Egge 1991). Thus, when cell size effects are eliminated, Pseudo-nitzschia appears to be a 'velocity' strategist (Sommer 1984), as is generally the case for small, r-selected diatoms (Litchman et al. 2007).

Pseudo-nitzschia had a high $v_{\max }$ and high $\alpha$ for both $\mathrm{NO}_{3}{ }^{-}$and $\mathrm{NH}_{4}{ }^{+}$relative to the dinoflagellate species in Table 4, indicating that Pseudo-nitzschia was a good competitor at both high and low concentrations, and this was reflected in its ability to thrive during both upwelling and relaxation.

However, $v_{\max }$ and $\alpha$ for $\mathrm{NO}_{3}^{-}$were lower in our study than in a Pseudo-nitzschia australis culture isolated from the Californian upwelling system (Cochlan et al. 2008) (Table 4). This could be explained by the nutrient history of the culture (Fan et al. 2003), which was grown on $70 \mu \mathrm{M} \mathrm{NO}_{3}{ }^{-}$as the sole nitrogen source. Although the medium was $\mathrm{NO}_{3}{ }^{-}$-depleted prior to starting the experiments, the cells were not nitrogenstarved; therefore, regulation of $v_{\max }$ and $\alpha$ in response to nitrogen depletion had most likely not yet taken place. The same order of preference was observed in the present study and in culture experiments using $P$. multiseries (Radan 2008) and P. cuspidata (Auro 2007), showing a general trend in preference for $\mathrm{NH}_{4}{ }^{+}$, as is often observed in phytoplankton due to the lower energetic cost of $\mathrm{NH}_{4}{ }^{+}$assimilation relative to $\mathrm{NO}_{3}{ }^{-}$ (Dortch 1990).

The Californian Pseudo-nitzschia australis also had a higher $v_{\text {max }}$ for $\mathrm{NH}_{4}{ }^{+}$than that in our study, even though it was not preconditioned with $\mathrm{NH}_{4}{ }^{+}$. If Pseudonitzschia in the California system responds as well to high $\mathrm{NH}_{4}{ }^{+}$concentrations as it does in culture, this would support the hypothesis that high anthropogenic $\mathrm{NH}_{4}{ }^{+}$concentrations $(>12 \mu \mathrm{M})$ are responsible for blooms of $P$. pseudodelicatissima on the Washington coast (Trainer et al. 2007). The $P$. australis culture had 
a similar $\alpha$ to that in our study, indicating that the Californian strain was more competitive at high $\mathrm{NH}_{4}{ }^{+}$but not at limiting $\mathrm{NH}_{4}{ }^{+}$concentrations.

\section{Dinophysis acuminata}

Although Gymnodinium spp. were responsible for $93 \%$ similarity within Type II, Dinophysis acuminata co-occurred with it at 3 of the 5 stations; hence, we assume that the 2 taxa were adapted to similar environmental conditions. Type II communities occurred under highly stratified, $\mathrm{NO}_{3}{ }^{-}$-depleted $(0.1$ to $0.5 \mu \mathrm{M})$ conditions and were even more dependent on recycled nitrogen than Types III and IV (mixed diatoms), with $f$-ratios of $\sim 0.1$. These species conform with the traditional concept of dinoflagellates being adapted to low nutrient concentrations and turbulence (Margalef 1978). D. acuta and G. catenatum-dominated communities present during the downwelling season in the Iberian upwelling system also rely on $\mathrm{NH}_{4}{ }^{+}$(Rios et al. 1995).

Dinophysis acuminata displayed a higher $v_{\max }$ and $\alpha$ for $\mathrm{NH}_{4}{ }^{+}$and urea than for $\mathrm{NO}_{3}{ }^{-}$, as did most dinoflagellate species in Table 4 . These species expressed a preference for recycled nitrogen and were better competitors for it at both saturating and limiting concentrations.

Dinophysis acuminata displayed lower $v_{\max }$ for $\mathrm{NO}_{3}{ }^{-}$ than all other species in Table 4 except Cochlodinium spp. (Kudela et al. 2008b), indicating that D. acuminata was not able to compete for high concentrations of $\mathrm{NO}_{3}{ }^{-}$, hence its appearance in the phytoplankton community after a long period of $\mathrm{NO}_{3}{ }^{-}$depletion. Maximum uptake of $\mathrm{NH}_{4}{ }^{+}$and urea was towards the middle of the range for dinoflagellates, whereas $\alpha$ was higher for $\mathrm{NH}_{4}^{+}$than in all other species including most diatoms. This suggests that $D$. acuminata is an 'affinity strategist' (Sommer 1984), well adapted to growing at very low $\mathrm{NH}_{4}{ }^{+}$and urea concentrations, although it was less competitive at low $\mathrm{NO}_{3}{ }^{-}$.

The difference in $\alpha$ for $\mathrm{NH}_{4}{ }^{+}$is also consistent with the higher temperature observed during the Dinophysis acuminata bloom, which would favour a higher $\alpha$ (Fan et al. 2003), although it is difficult to disentangle temperature effects from species-specific differences.

\section{CONCLUSIONS}

The southern Benguela is a highly dynamic region influenced by local wind patterns that drive upwelling/ relaxation cycles on timescales of days. This, in turn, influences community structure and the occurrence of HABs (Pitcher et al. 1998). The present study revealed extremely high variability in phytoplankton commu- nity structure in response to changes in the upwelling regime. We have sought to elucidate the nutritional characteristics of different HAB species and their link to variable nutrient regimes.

The toxic diatom Pseudo-nitzschia was favoured by upwelling and was able to rapidly utilise the high $\mathrm{NO}_{3}{ }^{-}$concentrations supplied by upwelling. Biomass accumulation occurred during wind relaxation, and Pseudo-nitzschia switched to $\mathrm{NH}_{4}{ }^{+}$as its main source of nitrogen as $\mathrm{NO}_{3}{ }^{-}$became depleted. Due to its small size, PN-specific $\nu_{\max }$ was high, as was $\alpha_{\text {; therefore, it }}$ was competitive at both saturating and limiting $\mathrm{NO}_{3}{ }^{-}$ and $\mathrm{NH}_{4}{ }^{+}$concentrations.

Alexandrium catenella bloomed at high $\mathrm{NO}_{3}{ }^{-}$concentrations, displayed high $f$-ratios and appeared to have a high requirement for $\mathrm{NO}_{3}{ }^{-}$since it disappeared when $\mathrm{NO}_{3}{ }^{-}$became depleted. The higher $v_{\max }$ for $\mathrm{NO}_{3}{ }^{-}$ indicated a preference for $\mathrm{NO}_{3}{ }^{-}$over recycled nitrogen, while the opposite has been observed in other dinoflagellate species in the California upwelling system, as well as for A. catenella blooms in the Thau Lagoon. We hypothesise that these differences were most likely due to differences in nutrient history and/or interspecific differences, although temperature differences were also considered.

Dinophysis acuminata bloomed under low $\mathrm{NO}_{3}{ }^{-}$concentrations and had low $f$-ratios and a higher $v_{\text {max }}$ for $\mathrm{NH}_{4}{ }^{+}$and urea than for $\mathrm{NO}_{3}{ }^{-}$, indicative of a preference for recycled nitrogen. Its high $\alpha$ values indicated a high affinity for recycled nitrogen sources, particularly $\mathrm{NH}_{4}{ }^{+}$, but a low affinity for $\mathrm{NO}_{3}{ }^{-}$, when compared with a range of $\mathrm{HAB}$ species. This high affinity for $\mathrm{NH}_{4}{ }^{+}$would have given it a competitive advantage under stratified conditions, despite its low affinity for $\mathrm{NO}_{3}^{-}$.

Acknowledgements. We thank D. Calder for chl a analyses and phytoplankton counts, A. du Randt for sample collection and $\mathrm{M}$. Bolshaw for technical support with the stable isotope mass spectrometer. This work was funded by Marine \& Coastal Management (MCM, South Africa), the Natural Environment Research Council (NERC, UK) (PhD Grant No. NER/ S/A/2005/13479) and the Abalone Farmer's Association of South Africa (AFASA). We also thank 4 anonymous reviewers for their helpful comments and suggestions.

\section{LITERATURE CITED}

Adams NA, Lesoing M, Trainer VL (2000) Environmental influences on domoic acid accumulation in razor clams on the Washington coast. J Shellfish Res 19:1007-1015

Aksnes DL, Egge JK (1991) A theoretical model for nutrient uptake in phytoplankton. Mar Ecol Prog Ser 70:65-72

Anderson DM, Kulis DM, Binder BJ (1984) Sexuality and cyst formation in the dinoflagellate Gonyaulax tamarensiscyst yield in batch cultures. J Phycol 20:418-425

Auro ME (2007) Nitrogen dynamics and toxicity of the pennate diatom Pseudo-nitzschia cuspidata. A field and labo- 
ratory based study. MSc thesis, San Francisco State University, CA

Avaria PS (1979) Red tides off the coast of Chile. In: Taylor DE, Seliger HH (eds) Proceedings of the 2nd international conference on toxic dinoflagellate blooms. Elsevier, New York, p 161-164

Bode A, Gonzalez N, Rodriguez C, Varela M, Varela MM (2005) Seasonal variability of plankton blooms in the Ria de Ferrol (NW Spain). I. Nutrient concentrations and nitrogen uptake rates. Estuar Coast Shelf Sci 63:269-284

Bravo I, Vila M, Maso M, Figueroa RI, Ramilo I (2008) Alexandrium catenella and Alexandrium minutum blooms in the Mediterranean Sea: toward the identification of ecological niches. Harmful Algae 7:515-522

Buck KR, Uttal-Cook L, Pilskaln CH, Roelke DL and others (1992) Autecology of the diatom Pseudonitzschia australis Frenguelli, a domoic acid producer from Monterey Bay, California. Mar Ecol Prog Ser 84:293-302

Caperon J, Meyer J (1972) Nitrogen-limited growth of marine phytoplankton. II. Uptake kinetics and their role in nutrient limited growth of phytoplankton. Deep-Sea Res 19: 619-632

Cochlan WP, Herndon J, Kudela RM (2008) Inorganic and organic nitrogen uptake by the toxigenic diatom Pseudonitzschia australis (Bacillariophyceae). Harmful Algae 8: $111-118$

Collos Y (1980) Transient situations in nitrate assimilation by marine diatoms. 1. Changes in uptake parameters during nitrogen starvation. Limnol Oceanogr 26:1075-1081

Collos Y, Slawyk G (1979) $\mathrm{C}^{13}$ and $\mathrm{N}^{15}$ uptake by marine phytoplankton. 1. Influence of nitrogen source and concentration in laboratory cultures of diatoms. J Phycol 15: 186-190

Collos Y, Gagne C, Laabir M, Vaquer A, Cecchi P, Souchu P (2004) Nitrogenous nutrition of Alexandrium catenella (Dinophyceae) in cultures and in Thau Lagoon, southern France. J Phycol 40:96-103

Collos Y, Vaquer A, Souchu P (2005) Acclimation of nitrate uptake by phytoplankton to high substrate levels. J Phycol 41:466-478

> Collos Y, Vaquer A, Laabir M, Abadie E, Laugier T, Pastoureaud A, Souchu P (2007) Contribution of several nitrogen sources to growth of Alexandrium catenella during blooms in Thau lagoon, southern France. Harmful Algae 6:781-789

Dortch Q (1990) The interaction between ammonium and nitrate uptake in phytoplankton. Mar Ecol Prog Ser 61: 183-201

Doyle RW (1975) Upwelling, clone selection and the characteristic shape of nutrient uptake curves. Limnol Oceanogr 20:487-489

Dugdale RC (1967) Nutrient limitation in the sea: dynamics, identification and significance. Limnol Oceanogr 12: 685-695

Dugdale RC, Wilkerson FP (1986) The use of ${ }^{15} \mathrm{~N}$ to measure nitrogen uptake in eutrophic oceans; experimental considerations. Limnol Oceanogr 31:673-689

Dugdale RC, Wilkerson FP, Morel A (1990) Realization of new production in coastal upwelling areas: a means to compare relative performance. Limnol Oceanogr 35:822-829

Dugdale RC, Wilkerson FP, Hogue VE, Marchi A (2006) Nutrient controls on new production in the Bodega Bay, California, coastal upwelling plume. Deep-Sea Res II 53: 3049-3062

Eppley RW, Peterson BJ (1979) Particulate organic-matter flux and planktonic new production in the deep ocean. Nature 282:677-680
Eppley RW, Rogers JN, McCarthy JJ (1969) Half-saturation constants for uptake of nitrate and ammonium by marine phytoplankton. Limnol Oceanogr 14:912-920

Fan C, Glibert PM, Burkholder JM (2003) Characterization of the affinity for nitrogen, uptake kinetics and environmental relationships for Prorocentrum minimum in natural blooms and laboratory cultures. Harmful Algae 2:283-299

Fawcett A, Pitcher GC, Bernard S, Cembella AD, Kudela RM (2007) Contrasting wind patterns and toxigenic phytoplankton in the southern Benguela upwelling system. Mar Ecol Prog Ser 348:19-31

- Glibert PM, Goldman JC, Carpenter EJ (1982a) Seasonal variations in the utilization of ammonium and nitrate by phytoplankton in Vineyard Sound, Massachusetts, USA. Mar Biol 70:237-250

Glibert PM, Lipschulz F, McCarthy JJ, Altabet MA (1982b) Isotope dilution models of uptake and remineralization of ammonium by marine plankton. Limnol Oceanogr 27: 639-650

Grasshoff K, Kremling K, Ehrhardt M (1999) Methods of seawater analysis. Wiley-Verlag Chemie, Weinheim

- Healey FP (1980) Slope of the Monod equation as an indicator of advantage in nutrient competition. Microb Ecol 5: 281-286

> Herndon J, Cochlan WP (2007) Nitrogen utilization by the raphidophyte Heterosigma akashiwo: growth and uptake kinetics in laboratory cultures. Harmful Algae 6:260-270

Hillebrand H, Durselen CD, Kirschtel D, Pollingher U, Zohary $\mathrm{T}$ (1999) Biovolume calculation for pelagic and benthic microalgae. J Phycol 35:403-424

Horner RA, Hickey BM, Postel JR (2000) Pseudo-nitzschia blooms and physical oceanography off Washington State, USA. S Afr J Mar Sci 22:299-308

Howard MDA, Cochlan WP, Ladizinsky N, Kudela RM (2007) Nitrogenous preference of toxigenic Pseudo-nitzschia australis (Bacillariophyceae) from field and laboratory experiments. Harmful Algae 6:206-217

Joyce LB, Pitcher GC (2004) Encystment of Zygabikodinium lenticulatum (Dinophyceae) during a summer bloom of dinoflagellates in the southern Benguela upwelling system. Estuar Coast Shelf Sci 59:1-11

Kudela RM, Cochlan WP (2000) Nitrogen and carbon uptake kinetics and the influence of irradiance for a red tide bloom off southern California. Aquat Microb Ecol 21: $31-47$

Kudela RM, Lane JQ, Cochlan WP (2008a) The potential role of anthropogenically derived nitrogen in the growth of harmful algae in California, USA. Harmful Algae 8: 103-110

Kudela RM, Ryan JP, Blakely MD, Lane JQ, Peterson TD (2008b) Linking the physiology and ecology of Cochlodinium to better understand harmful algal bloom events: a comparative approach. Harmful Algae 7:278-292

> Litchman E, Klausmeier CA, Schofield OM, Falkowski PG (2007) The role of functional traits and trade-offs in structuring phytoplankton communities: scaling from cellular to ecosystem level. Ecol Lett 10:1170-1181

Lomas MW, Glibert PM, Berg GM, Burford M (1996) Characterization of nitrogen uptake by natural populations of Aureococcus anophagefferens (Chrysophyceae) as a function of incubation duration, substrate concentration, light, and temperature. J Phycol 32:907-916

MacIsaac JJ, Dugdale RC (1969) The kinetics of nitrate and ammonia uptake by natural populations of marine phytoplankton. Deep-Sea Res 14:45-57

Maguer JF, Wafar M, Madec C, Morin P, Erard-Le Denn E (2004) Nitrogen and phosphorous requirements of an 
Alexandrium minutum bloom in the Penze Estuary, France. Limnol Oceanogr 49:1108-1114

Malone TC (1980) Algal size. In: Morris I (ed) The physiological ecology of phytoplankton. Blackwell, London, p 433-464

Marchetti A, Trainer VL, Harrison PJ (2004) Environmental conditions and phytoplankton dynamics associated with Pseudo-nitzschia abundance and domoic acid in the Juan de Fuca eddy. Mar Ecol Prog Ser 281:1-12

Margalef R (1978) Life-forms of phytoplankton as survival alternatives in an unstable environment. Oceanol Acta 1:493-509

Margalef R, Estrada M, Blasco D (1979) Functional morphology of organisms involved in red tides, as adapted to decaying turbulence. In: Taylor D, Seliger HH (eds) Toxic dinoflagellate blooms. Elsevier, New York, p 89-94

Matsuda A, Nishijima T, Fukami K (1999) Effects of nitrogenous and phosphorus nutrients on the growth of toxic dinoflagellate Alexandrium catenella. Nippon Suisan Gakkaishi 65:847-855

McCarthy JJ, Taylor WR, Taft JL (1977) Nitrogenous nutrition of the plankton in the Chesapeake Bay, Part I. Nutrient availability and phytoplankton preferences. Limnol Oceanogr 22:996-1011

Menden-Deuer S, Lessard EJ (2000) Carbon to volume relationships for dinoflagellates, diatoms and other protist plankton. Limnol Oceanogr 45:569-579

Nishitani L, Chew K (1988) PSP toxins in the Pacific coast states USA monitoring programs and effects on bivalve industries. J Shellfish Res 7:653-670

Nydahl F (1976) On the optimum conditions for the reduction of nitrate to nitrite by cadmium. Talanta 23:349-357

Parsons TR, Maita Y, Lalli CM (1984) A manual of chemical and biological methods for seawater analysis. Pergamon Press, Oxford

Pitcher GC, Boyd AJ (1996) Across-shelf and alongshore dinoflagellate distributions and the mechanisms of red tide formation within the southern Benguela upwelling system. In: Yasumoto T, Oshima Y, Fukuyo Y (eds) Harmful and toxic algal blooms. Intergovernmental Oceanographic Commission of UNESCO, Paris, p 243-246

Pitcher GC, Calder D (2000) Harmful algal blooms of the southern Benguela current: a review and appraisal of monitoring from 1989 to 1997. S Afr J Mar Sci 22: 255-271

Pitcher GC, Nelson G (2006) Characteristics of the surface boundary layer important to the development of red tide on the southern Namaqua shelf of the Benguela upwelling system. Limnol Oceanogr 51:2660-2674

Pitcher GC, Horstman DA, Calder D (1993a) Formation and decay of red tide blooms in the southern Benguela upwelling system during the summer of 1990/91. In: Smayda TJ, Shimizu Y (eds) Toxic phytoplankton blooms in the sea. Elsevier, New York, p 317-322

Pitcher GC, Horstman DA, Calder D, De Bruyn JH, Post BJ (1993b) The first record of diarrhetic shellfish poisoning on the South African coast. S Afr J Sci 89:512-514

Pitcher GC, Boyd AJ, Horstman DA, Mitchell-Innes BA (1998) Subsurface dinoflagellate populations, frontal blooms and the formation of red tide in the southern Benguela upwelling system. Mar Ecol Prog Ser 172:253-264

Pitcher GC, Cembella AD, Joyce LB, Larsen J, Probyn TA, Sebastian CR (2007) The dinoflagellate Alexandrium minutum in Cape Town harbour (South Africa): bloom characteristics, phylogenetic analysis and toxin composition. Harmful Algae 6:823-836
Probyn TA (1985) Nitrogen uptake by size-fractionated phytoplankton populations in the southern Benguela upwelling system. Mar Ecol Prog Ser 22:249-258

Probyn TA (1987) Ammonium regeneration by microplankton in an upwelling environment. Mar Ecol Prog Ser 37:53-64

Probyn TA (1992) The inorganic nitrogen nutrition of phytoplankton in the southern Benguela: new production, phytoplankton size and implications for pelagic foodwebs. In: Payne AIL, Brink KH, Mann KH, Hilborn R (eds) Benguela trophic functioning. S Afr J Mar Sci 12:411-420

Probyn TA, Pitcher GC, Monteiro PMS, Boyd AJ, Nelson G (2000) Physical processes contributing to harmful algal blooms in Saldanha Bay, South Africa. S Afr J Mar Sci 22:285-297

Radan RL (2008) Nitrogen uptake and domoic acid production by the toxigenic diatom Pseudo-nitzschia multiseries. MS thesis, San Francisco State University, CA

Reguera B, Marino J, Campos MJ, Bravos I, Fraga S, Carbonell A (1993) Trends in the occurrence of Dinophysis spp. in Galician waters. In: Smayda TJ, Shimizu Y (eds) Toxic phytoplankton blooms in the sea. Elsevier, New York, p 559-564

> Riegman R, De Boer M, De Senerpont Domis L (1996) Growth of harmful marine algae in multispecies cultures. J Plankton Res 18:1851-1866

Rios AF, Fraga F, Figueiras FG, Perez FF (1995) New and regenerated production in relation to proliferations of diatoms and dinoflagellates in natural conditions. In: Lassus P, Arzul G, Erard Le Denn E, Gentien P, Marcaillou Le Baut C (eds) Harmful marine algal blooms. Lavoisier, Paris, p 663-668

Shannon CE (1948) A mathematical theory of communication. Bell Syst Tech J 27:379-423 and 623-656

Siu GKY, Young MLC, Chan DKO (1997) Environmental and nutritional factors which regulate population dynamics and toxin production in the dinoflagellate Alexandrium catenella. Hydrobiologia 352:117-140

Smayda TJ (1997) Harmful algal blooms: their ecophysiology and general relevance to phytoplankton blooms in the sea. Limnol Oceanogr 42:1137-1153

Sommer U (1984) The paradox of the plankton — fluctuations of phosphorus availability maintain diversity of phytoplankton in flow-through cultures. Limnol Oceanogr 29:633-636

Stolte W, Riegman R (1996) The relative preference index (RPI) for phytoplankton nitrogen use is only weakly related to physiological preference. J Plankton Res 18: 1041-1045

Tilstone GH, Figueiras FG, Fraga F (1994) Upwelling-downwelling sequences in the generation of red tides in a coastal upwelling system. Mar Ecol Prog Ser 112:241-253

Trainer VL, Adams NG, Wekell JC (2001) Domoic acid-producing Pseudo-nitzschia species off the US west coast associated with toxification events In: Hallegraeff GM, Blackburn SI, Bolch CJ, Lewis RJ (eds) Harmful algal blooms. Intergovernmental Oceanographic Commission of UNESCO, Paris, p 46-49

Trainer VL, Hickey BM, Horner RA (2002) Biological and physical dynamics of domoic acid production off the Washington coast. Limnol Oceanogr 47:1438-1446

Trainer VL, Cochlan WP, Erickson A, Bill BD, Cox FH, Borchert JA, Lefebvre KA (2007) Recent domoic acid closures of shellfish harvest areas in Washington State inland waterways. Harmful Algae 6:449-459

Utermöhl H (1958) Zur Vervollkommnung der quantitativen Phytoplankton Methodik. Mitt Int Ver Theor Angew Limnol 9:1-38

Submitted: July 8, 2008; Accepted: December 19, 2008

Proofs received from author(s): March 14, 2009 